\title{
norden
}

Pohioismaiden ministerineuvosto

\section{Rikkaampi tulevaisuus}

13 yleissopimusta luonnon ja kulttuuriympäristön hyväksi

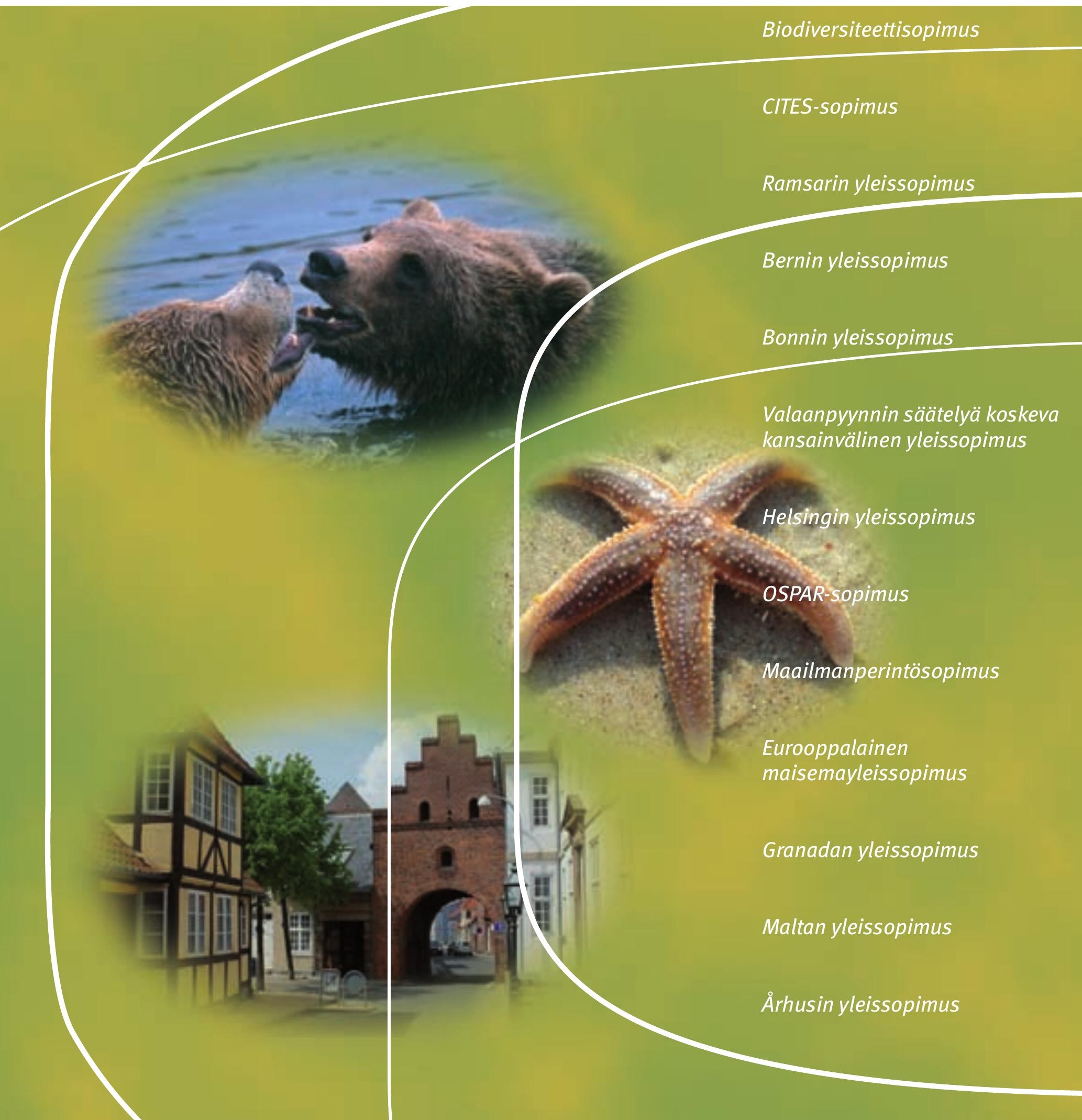




\section{Rikkaampi tulevaisuus}

13 yleissopimusta luonnon ja kulttuuriympäristön hyväksi

TemaNord 2006:562 


\section{Rikkaampi tulevaisuus}

13 yleissopimusta luonnon ja kulttuuriympäristön hyväksi

TemaNord 2006:562

(C) Pohjoismaiden ministerineuvosto, Kööpenhamina 2006

ISBN 92-893-1375-7

Paino: UniTryk

Ulkoasu ja toimitus: Naturplan (www.naturplan.dk)

Kannen valokuva: Mark Desholm, Naturplan; Inge-Marie Fruelund/Naturplan; Stig Bachmann Nielsen/Naturplan Taustakuva: Kurt Petersen/Scanpix s. 10; Claro Cortes IV/Scanpix s. 14; Johnny Madsen/Scanpix s. 16; Birthe Overgaard/Naturplan S. 18, 28; Klaus Mortensen/Naturplan S. 20; Jens Muff Hansen/Naturplan S. 24, 32; IngeMarie Fruelund/Naturplan s. 26; Sven Halling/Scanpix s. 30; Grethe Bachmann/Naturplan s. 34; Stig Bachmann Nielsen/Naturplan s. 36; Erik Smedegaard/Scanpix s. 38.

Painos: 2000

Painettu ympäristöä säästävälle paperille, joka täyttää pohjoismaisen Joutsenmerkin kriteerit.

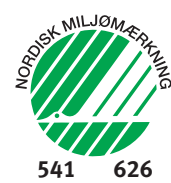

Julkaisua voi tilata osoitteesta www.norden.org/order. Muita julkaisuja on osoitteessa www.norden.org/publikationer

Printed in Denmark

\section{Nordisk Ministerråd}

Store Strandstræde 18

DK-1255 København K

Puh. (+45) 33960200

Faksi (+45) 33960202

\section{Nordisk Råd}

Store Strandstræde 18

DK-1255 København K

Puh. (+45) 33960400

Faksi (+45) 33111870

www.norden.org

\section{Pohjoismainen yhteistyö}

Pohjoismainen yhteistyö on maailman vanhimpia ja kattavimpia alueellisen yhteistyön malleja. Siihen osallistuvat Islanti, Norja, Ruotsi, Suomi ja Tanska sekä Ahvenanmaan, Färsaarten ja Grönlannin itsehallintoalueet. Yhteistyö vahvistaa Pohjoismaiden yhteenkuuluvuutta unohtamatta maiden välisiä yhtäläisyyksiä ja kansallisia erityispiirteitä. Lisäksi se parantaa naapuruussuhteita ja mahdollisuuksia pohjoismaiseen edunvalvontaan kansainvälisissä yhteyksissä.

Pohjoismainen yhteistyö sai viralliset puitteet vuonna 1952, jolloin Pohjoismaiden neuvosto perustettiin maiden parlamenttien ja hallitusten yhteistyöelimeksi. Vuonna 1962 Pohjoismaat allekirjoittivat Helsingin sopimuksen, joka on edelleenkin pohjoismaisen yhteistyön kulmakivi. Vuonna 1971 perustettiin Pohjoismaiden ministerineuvosto, joka on viiden Pohjoismaan sekä kolmen itsehallintoalueen hallitusten välinen yhteistyöelin. 
Esipuhe $\quad 6$

$\begin{array}{ll}\text { Rikkaampi tulevaisuus } & 8\end{array}$

Biologista monimuotoisuutta koskeva yleissopimus 10

$\begin{array}{ll}\text { CITES-sopimus } & 14\end{array}$

Ramsarin yleissopimus 16

$\begin{array}{ll}\text { Bernin yleissopimus } & 18\end{array}$

Bonnin yleissopimus $\quad 20$

Valaanpyyntisopimus $\quad 24$

Helsingin yleissopimus $\quad 26$

$\begin{array}{ll}\text { OSPAR-sopimus } & 28\end{array}$

Maailmanperintösopimus 30

Eurooppalainen maisemayleissopimus 32

Granadan yleissopimus $\quad 34$

Maltan yleissopimus $\quad 36$

Århusin yleissopimus $\quad 38$

Kansainväliset sihteeristöt $\quad 40$ 


\section{Esipuhe}

Pohjoismaat ovat osaltaan olleet vaikuttamassa siihen, että maailman yhteistä luonto- ja kulttuuriperintöä suojellaan useiden yleissopimusten avulla.

Yleissopimuksilla turvataan lajirikas luonto ja erilaiset elinympäristöt. Luonnon monimuotoisuus on arvo itsessään ja sillä on suuri merkitys sosiaaliselle ja taloudelliselle kehitykselle kaikkialla maailmassa. Hyvinvoiva ja puhdas ympäristö vaikuttaa myös ihmisen terveyteen, viihtyvyyteen ja elämänlaatuun.

Yleissopimuksiin liittyvässä työssä kiinnitetäänkin yhä enemmän huomiota maailman kulttuuriperinnön suojelemisen merkitykseen, varsinkin arkkitehtuuriltaan tietylle paikalle tai ajalle ominaisiin rakennuksiin, kaupunkeihin, joissa on runsaasti arkeologisia löydöksiä tai muinaisjäännöksiä tai alueisiin, joilta yhä löytyy menneisyyden ja nykyisyyden yhdistäviä eläviä kulttuuriympäristöjä. Kulttuuriperinnöt tarjoavat meille historiallisen tietoisuuden ja ovat tärkeänä perustana omalle identiteetillemme - mistä ikinä olemmekin kotoisin.

Yhteisten kulttuuri- ja luontoarvojen turvaaminen on tärkeä asia Pohjoismaille. Tässä työssä yleissopimukset ovat merkittävä työkalu, sillä parhaimmat tulokset saavutetaan tekemällä yhteistyötä yli kansallisten rajojen.

Tässä vihkosessa esitellään lyhyesti 13 tärkeintä luonto- ja kulttuuriperintöjen suojeluun liittyvää yleissopimusta, joissa Pohjoismaat ovat mukana ja joiden laatimiseen Pohjoismaat useassa tapauksessa ovat osallistuneet.

Tavoitteena on antaa parempi tietämys yleissopimuksista - niin poliitikoille, hallinnon edustajille, opettajille kuin muillekin luonto- ja kulttuuriperinnöstämme kiinnostuneille.

Esitteen julkaiseminen yhteisesti kuvastaa pitkää perinnettä, joka pohjoismaisella yhteistyöllä on kansainvälisesti merkittävissä asioissa. Toimiva yhteistyö yleissopimusten osalta lisää niiden maailmanlaajuista vaikuttavuutta - sekä nykyisten että tulevien sukupolvien iloksi - ja samanaikaisesti vahvistaa pohjoismaista yhteishenkeä.

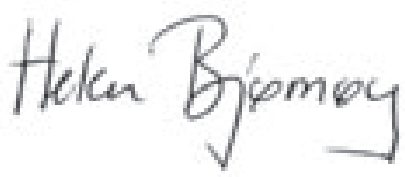

Helen Bjørnøy

Ympäristöministeri

Norja

Pohjoismaiden ministerineuvoston, ympäristönsuojelusta ja kulttuuriperinnön säilyttämisestä vastaavien ministerien puolesta 


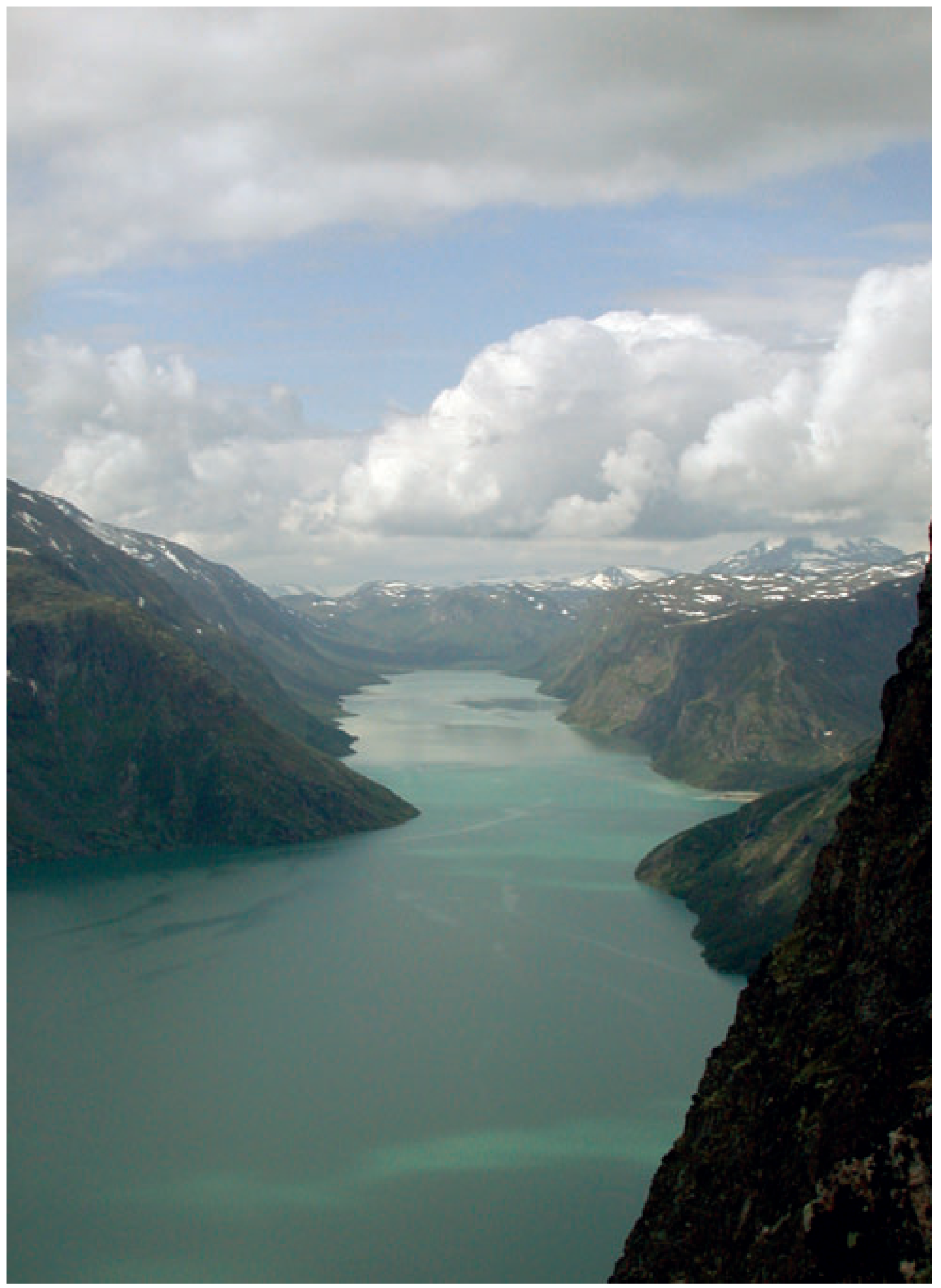

Gjende, Jotunheimenin kansallispuisto, Norja (kuva: Jens Muff Hansen/Naturplan). 


\section{Rikkaampi tulevaisuus}

Pohjoismaiden luonnon- ja kulttuuriympäristön suojelulla on pitkät perinteet. Luonto- ja kulttuuriarvojen suojelu oli pitkään jokaisen maan oma asia, mutta sittemmin suojelu on saanut kansainvälisempiä piirteitä.

\section{Kansainväliset järjestöt}

Maailman vanhin kansainvälinen luonnonsuojelujärjestö perustettiin vuonna 1922. Se oli nimeltään Kansainvälinen lintujensuojeluneuvosto eli ICBP, josta myöhemmin tuli BirdLife International. Vuonna 1948 perustettiin Maailman luonnonsuojeluliitto (IUCN) ja kansainvälinen yhteistyö maailmanlaajuisen ympäristökriisin pysäyttämiseksi pääsi kunnolla vauhtiin. Tämän jälkeen on perustettu useita erilaisia kansainvälisiä luonnonsuojelu- ja ympäris- töjärjestöjä, jotka ovat vaikuttaneet siihen, että valtiot ovat yhdessä päättäneet edistää luonnon- ja kulttuuriarvojen suojelua. Tämä on useissa tapauksissa johtanut kansainvälisten yleissopimusten laatimiseen.

\section{Mitä yleissopimukset ovat?}

Yleissopimukset ovat kansallisen oikeuden mukaan sitovia valtioiden välisiä sopimuksia. Monet yleissopimukset ovat koko maapallon kattavia kun taas toiset koskevat esimerkiksi ainoastaan Eurooppaa tai tiettyä Euroopan osaa. Jäsenvaltiot tapaavat säännöllisesti neuvotellakseen yleissopimukseen liittyvistä velvollisuuksista. Biodiversiteettiin liittyvien sopimusten jäsenet sopivat myös tarpeesta tehdä muutoksia asianomaisen yleissopimuksen liitteisiin sisältyvien eläin- ja kasvilajien, alueiden jne. suhteen.

\section{3 yleissopimusta pohjoismaisesta näkökulmasta katsottuna}

Kaikki Pohjoismaat ovat allekirjoittaneet luonnon, ympäristön ja kulttuuriympäristön käyttöä ja suojelua sääteleviä yleissopimuksia. Tässä vihkosessa käydään läpi 13 kattavinta sopimusta, jotka koskevat Pohjoismaita. Kyseiset yleissopimukset on esitetty taulukossa oikealla.

Vihkosessa esitellään lyhyesti yleissopimukset ja kerrotaan, mistä saa lisätietoa.

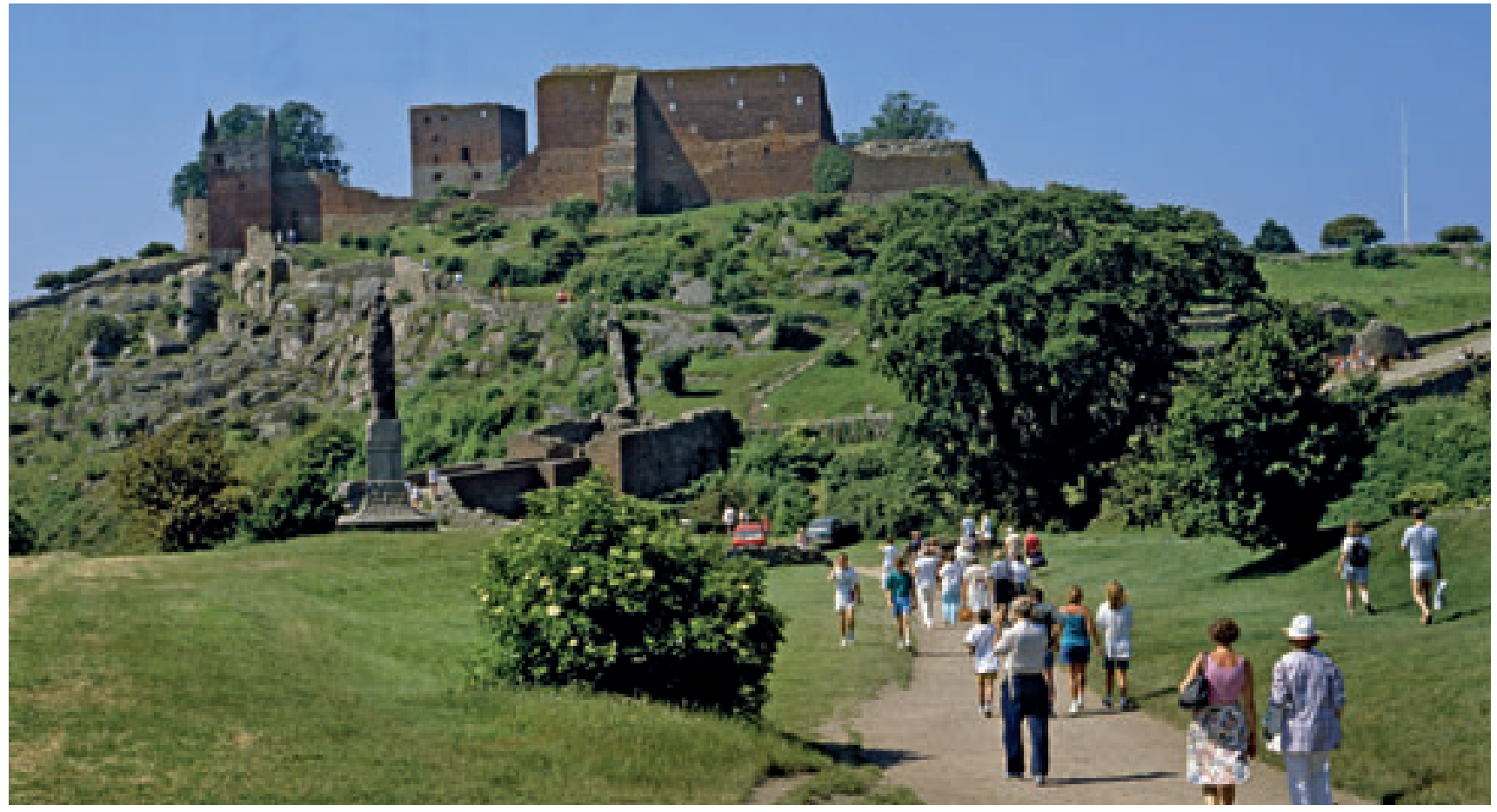




\section{Luontoa koskevat yleissopimukset}

Biodiversiteettisopimus

(The Convention on Biological Diversity)

CITES-sopimus

(The Convention on International Trade in Endangered Species of Wild Fauna and Flora)

Ramsarin yleissopimus

(Convention on Wetlands of International Importance especially as Waterfowl Habitat)

Bernin yleissopimus

(The Convention of European Wildlife and Natural Habitats)

Bonnin yleissopimus

(Convention on Migratory Species of Wild Animals)

Valaanpyynnin säätelyä koskeva kansainvälinen yleissopimus (International Convention for the Regulation of Whaling)

\section{Merialueita koskevat yleissopimukset}

Helsingin yleissopimus (Sopimus Itämeren suojelusta)

(Convention on the Protection of the Marine Environment of the

Baltic Sea Area)

OSPAR-sopimus

(Convention for the protection of the marine environment of the North-east Atlantic)

\section{Kulttuuria ja maisemaa koskevat yleissopimukset}

\section{Maailmanperintösopimus}

(Convention Concerning the Protection Of The Cultural and Natural Heritage)

Eurooppalainen maisemayleissopimus

(the European Landscape Convention)

Granadan yleissopimus

(Convention for the Protection of Architectural Heritage in Europe)

Maltan yleissopimus

(Convention on the Projection of Archaeological Heritage in Europe)

\section{Yleistä}

Århusin yleissopimus

(The Convention on Access to Information, Public Participation in Decision Making and Access to Justice in Environmental Matters)
Rio De Janeiro 1992

Washington

1973

Ramsar

1971

Bern

1979

Bonn

Washington 1946

Helsinki

1992

Pariisi

1992

Pariisi

1972

Firenze

2000

Granada

1985

Valletta

1992

Århus

Merkkien selitys:

+ Maa on sitoutunut noudattamaan yleissopimusta

- Maa ei ole sitoutunut noudattamaan yleissopimusta 


\title{
Biologista monimuotoisuutta koskeva yleissopimus
}

\author{
Biodiversiteettisopimus
}

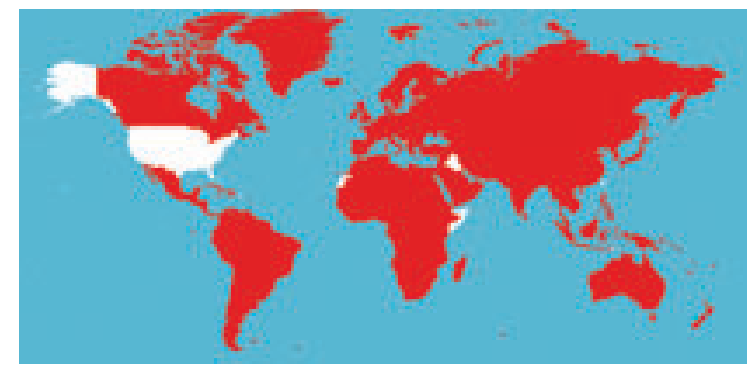

Biologista monimuotoisuutta koskeva yleissopimus (CBD) hyväksyttiin Rio de Janeirossa 1992. Maailmanlaajuisessa kestävän kehityksen huippukokouksessa Johannesburgissa 10 vuotta myöhemmin yli 150 maan päämiehet vahvistivat, että yleissopimus on maapallon biologisen monimuotoisuuden säilyttämisen tärkein väline.

Yleissopimus on tulosta siitä, että kansainvälinen yhteisö oli huolissaan biologisen monimuotoisuuden katoamisesta, ja sopimuksessa korostetaan sitä, että biologisen monimuotoisuuden häviämistä on tarpeen hillitä - suojelulla ja kestävällä käytöllä.

Tällä hetkellä 188 maata on liittynyt yleissopimukseen. Yleissopimus koskee myös kaikkia Pohjoismaita.

\section{Mitä biologisella monimuotoisuudella tarkoitetaan?}

Biologisella monimuotoisuudella eli biodiversiteetillä tarkoitetaan kasvien, eläinten ja mikro-organismien monimuotoisuutta sekä ekosysteemien, jonka osana lajit ovat, monimuotoisuutta. Myös lajien sisäinen perinnöllinen monimuotoisuus lasketaan biologiseen monimuotoisuuteen kuuluviksi. Biologinen monimuotoisuus on syntynyt miljoonien vuosien evoluutiossa.

\section{Yleissopimuksen tarkoitus}

Biodiversiteettisopimuksen tarkoituksena on samalla kertaa suojella biologista monimuotoisuutta, varmistaa biologisten luonnonvarojen kestävä käyttö sekä varmistaa, että perintöaineksen hyödyntämisestä saatava tuotto jakautuu oikeudenmukaisesti maiden kesken.

YK:n Vuosituhannen ekosysteemiarviointi vuodelta 2005 (Millenium Ecosystem Assessment) osoittaa, että ihmiset ovat aiheuttaneet viimeisten 50 vuoden aikana suurempia ekosysteemien muutoksia kuin muina aikoina ihmisen historiassa. Se nopeus, jolla lajeja kuolee tällä hetkellä sukupuuttoon, on kohonnut 50-100 -kertaiseksi. Tärkeimpiä syitä ovat elinympäristöjen tuhoutuminen, haitalliset tulokaslajit, liikahyödyntäminen, ilmastonmuutokset ja saastuminen. Samalla YK:n raportti korostaa ihmisen riippuvuutta biologisesta monimuotoisuudesta ihmiskunnan säilymisen, uusien arvojen luomisen, hyvinvoinnin ja viihtyisyyden suhteen.

Suurin osa geneettisestä monimuotoisuudesta on kehitysmaissa, mutta teollisuusmailla on teknologia, jolla näitä luonnonvaroja voidaan hyödyntää kaupallisesti. Yleissopimuksessa kannustetaan kehittämään mekanismeja, jotka varmistavat geenivaroista saatavien hyötyjen oikeudenmukaisen jakamisen.

\section{0 tavoite}

Kestävän kehityksen huippukokouksessa 2002 maat päättivät vähentää merkittävästi biologisen monimuotoisuuden häviämistä ihmisen toiminnan seurauksena vuoteen 2010 mennessä. Kiovan ympäristöministerikokouksessa 2003 Euroopan ympäristöministerit olivat yksimielisiä siitä, että Euroopalle on määrättävä kunnianhimoisempi tavoite. Tavoitteena on, että biologisen monimuotoisuuden häviäminen pysäytetään kokonaan vuoteen 2010 mennessä. Tämän tulee tapahtua muun muassa luomalla suojelualueiden ekologisia verkostoja. 


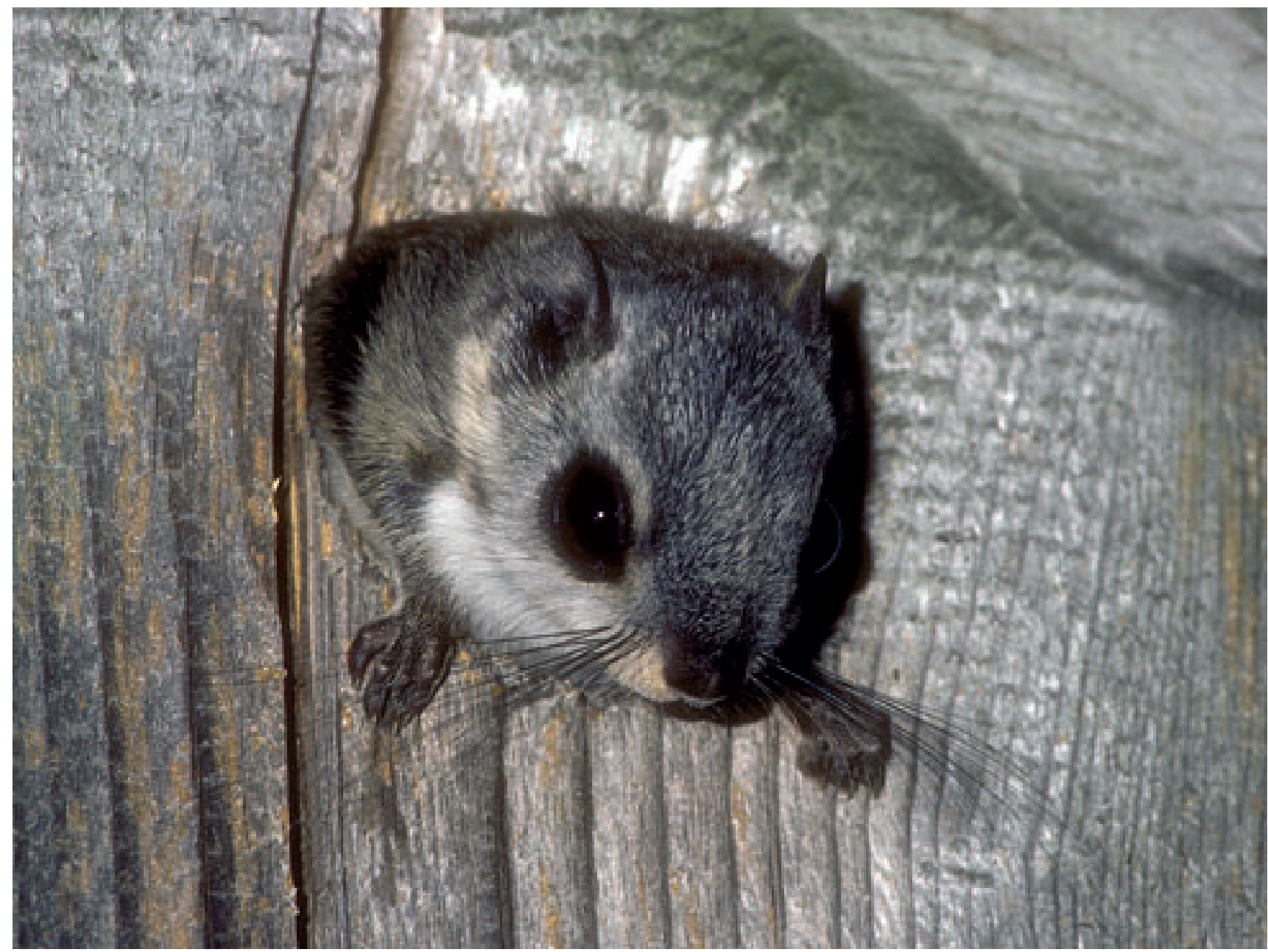

Liito-orava (Pteromys volans) ei esiinny muissa Pohjoismaissa kuin Suomessa. Suomessa laji on taantumassa. Syynä lajin taantumiseen on tehostunut metsätalous (kuva: Jussi Murtosaari).

\section{Miten sopimus toimii?}

Jäsenmaiden tulee kehittää kansallisia biologisen monimuotoisuuden suojelun ja kestävän käytön strategioita ja toimintasuunnitelmia. Rikkaat maat ovat myös vastuussa siitä, että ne auttavat köyhiä maita yleissopimuksen toteuttamisessa.

Yleissopimusta kehitetään edelleen laatimalla työohjelmia ja selvityksiä sekä valmistamalla juridisesti sitovia pöytäkirjoja.

Yleissopimuksessa todetaan, että ihminen on osa luontoa ja että meidän tulee hyödyntää biologisia luonnonvaroja, mutta että meidän on samalla seurattava sitä, millä tavalla tämä vaikuttaa ekosysteemeihin.

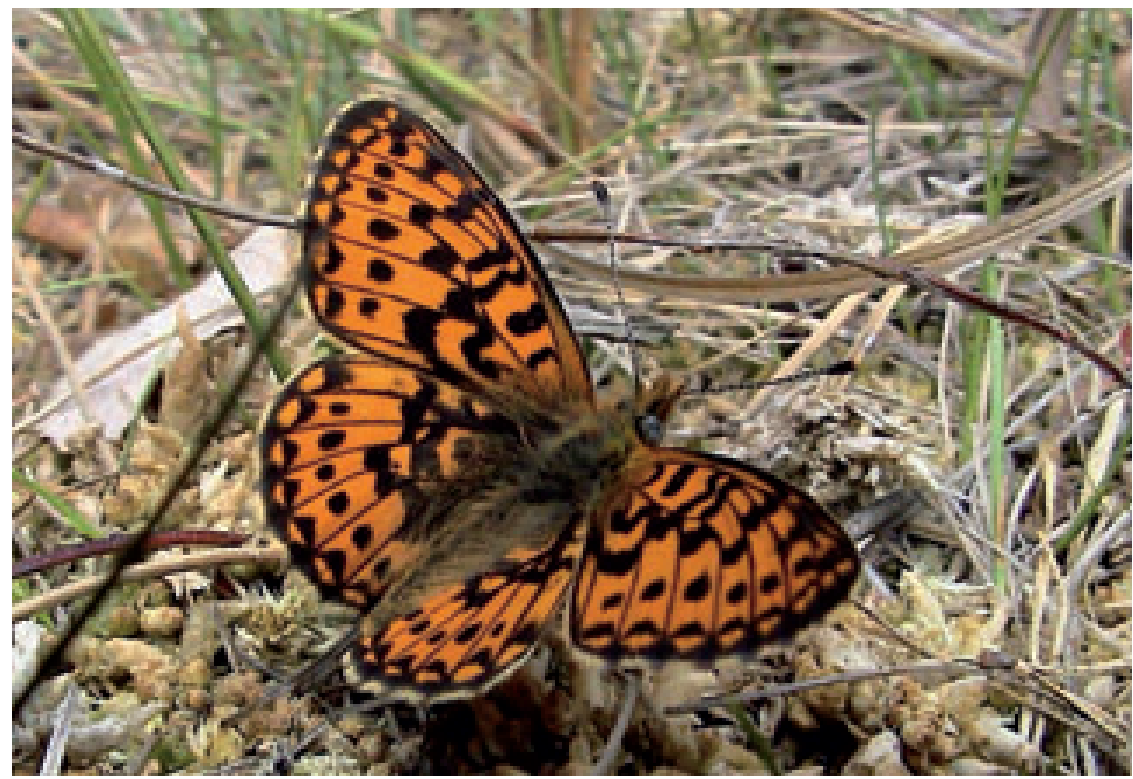

Perhoset ovat riippuvaisia tietyistä isäntäkasveista. Suohopeatäplä (Boloria aquilonaris) on riippuvainen karpalosta. Jos karpaloiden kasvupaikat, kohosuot, häviävät, häviävät myös suohopeatäplän elinympäristöt (kuva: Andis Liepa/Naturplan). 


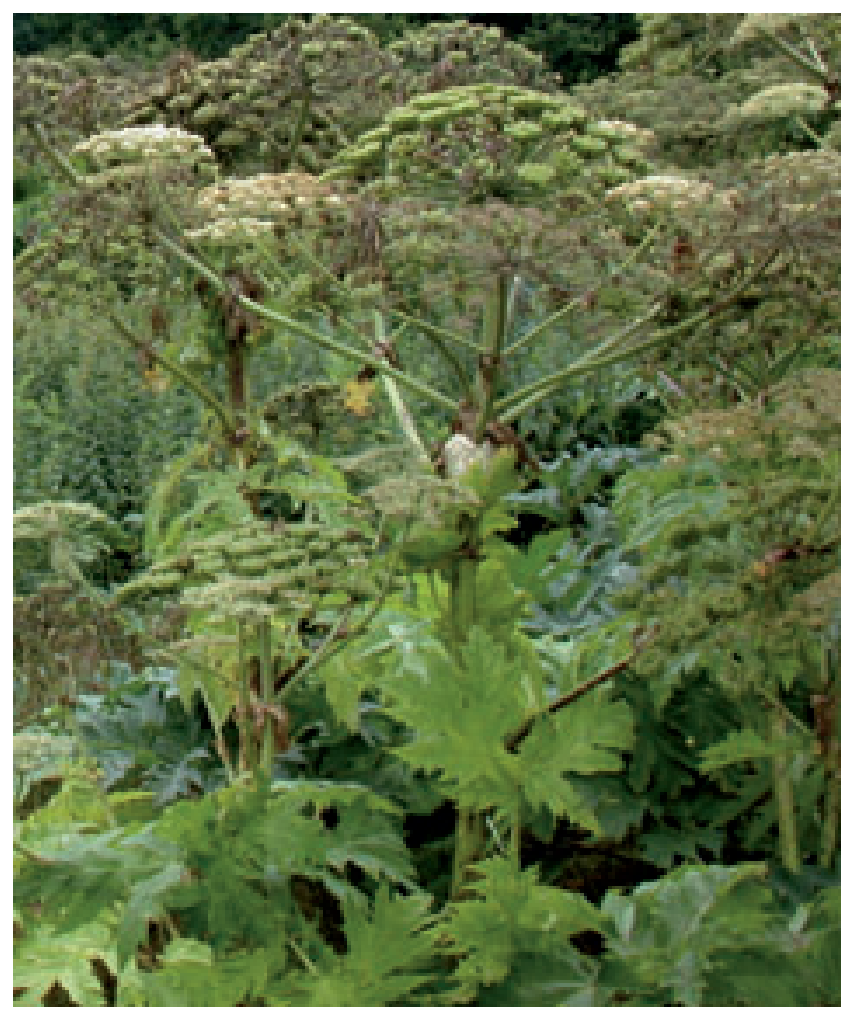

Pohjoismais-baltialainen yhteistyö, NOBANIS, on käynnistetty tarkoituksena estää invaasioherkkien tulokaslajien kuten esimerkiksi kaukasianjättiputken (Heracleum mantegazzianum) leviäminen (kuva: Jens Muff Hansen/Naturplan).

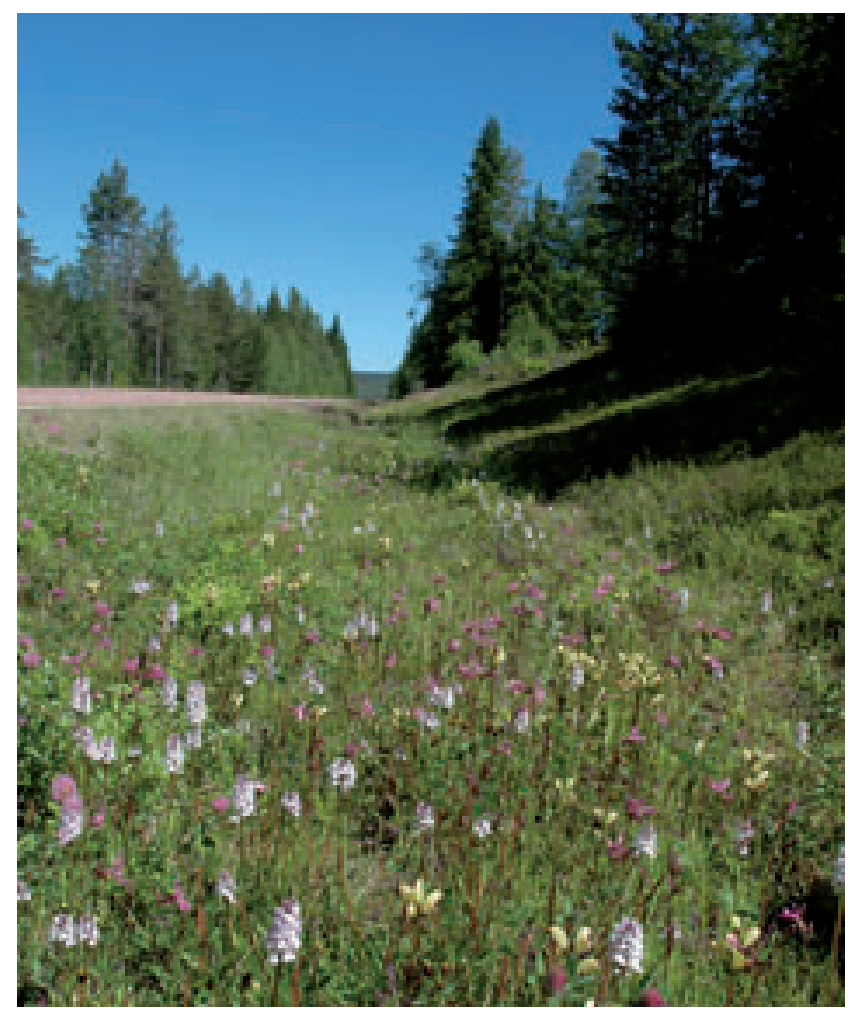

Vaihteleva maisema, jossa esiintyy monia luontotyyppejä, tarioaa elinmahdollisuudet monille lajeille (Indlandsvägen, Ruotsi) (kuva: Carsten Brandt).

\section{Tiedotus ja tiedostaminen}

On tärkeää, että niin monet ihmiset kuin mahdollista ymmärtävät, minkä takia biologisen monimuotoisuuden säilyttäminen on välttämätöntä. Yleissopimukseen liittyessään jäsenmaat ovat ottaneet vastuulleen sen, että ne tiedottavat väestölleen lajien ja elinympäristöjen merkityksestä.

\section{Geenivarat}

Yleissopimus takaa, että jokaisella maalla on täysivaltainen oikeus hyödyntää omia luonnonvarojaan.

Geenivaroilla on suuri taloudellinen merkitys bioteknologian, lääkkeiden, kosmetiikan, viljelyn, jalostuksen jne. raaka-aineina. Arviolta noin $40 \%$ maailmantaloudesta perustuu biologisiin tuotteisiin ja prosesseihin.
Kansainvälisen pohdinnan kohteena on kysymys, millä tavoin tulee suhtautua geenivarojen omistus- ja käyttöoikeuteen. Teollisuus perustelee patenttien käyttöä siten, että geenivarojen tutkiminen on välttämätöntä uusien lääkkeiden kehittämistä ja muun muassa elintarvikkeiden ja maanviljelyn kehittämistä varten - mikä koituu koko ihmiskunnan hyväksi. Patenttien epäkohtana on, että kehitys johtaa siihen, että geenivarat ovat vain niiden käytettävissä, joilla on taloudelliset resurssit maksaa niistä. Samalla kysymys omistusoikeudesta saattaa aiheuttaa ongelmia alkuperäiskansojen ja muiden paikallisyhteisöjen perinteisten tietojen ja taitojen suhteen.

\section{Alkuperäiskansat ja perinnetieto}

Biologista monimuotoisuutta koskevassa yleissopimuksessa on erityinen työohjelma alkuperäis- kansoja ja paikallisyhteisöjä varten, joiden elämä perustuu perinteisiin tapoihin.

\section{Pohjoismainen yhteistyö}

Pohjoismaat ovat kehittäneet yhteistyössä - Pohjoismaisen Ministerineuvoston johdolla - pohjoismaisen geenivarastrategian. Pohjoismaisen yhteistyön tarkoituksena on vahvistaa työtä, jota tehdään geneettisen monimuotoisuuden säilyttämiseksi ja kestäväksi hyödyntämiseksi maaja metsätaloudessa ja kalastuksessa sekä elintarvikkeiden osalta. Yhteistyö auttaa osaltaan toteuttamaan sopimuksen geenivarojen saatavuutta ja oikeuksia koskevia tavoitteita.

Haitallisia tulokaslajeja koskeva yhteistyö (NOBANIS) on käynnistetty Pohjoismaiden ja Baltian välillä. 


\section{Bioturvapöytäkirja (Cartagenan pöytäkirja)}

Tammikuussa 2000 jäsenmaat solmivat lisäsopimuksen, bioturvapöytäkirjan eli Cartagenan pöytäkirjan, joka koskee eläviä muuntogeenisiä organismeja (LMO eli GMO)). Yleissopimuksen on määrä varmistaa riittävä ympäristönsuojelu, kun eläviä muuntogeenisiä organismeja siirretään yli valtioiden rajojen ja käytetään kansainvälisesti.

Islantia lukuun ottamatta kaikki Pohjoismaat ovat ratifioineet Cartagenan pöytäkirjan. Tanskan liittyminen ei koske Färsaaria eikä Grönlantia.

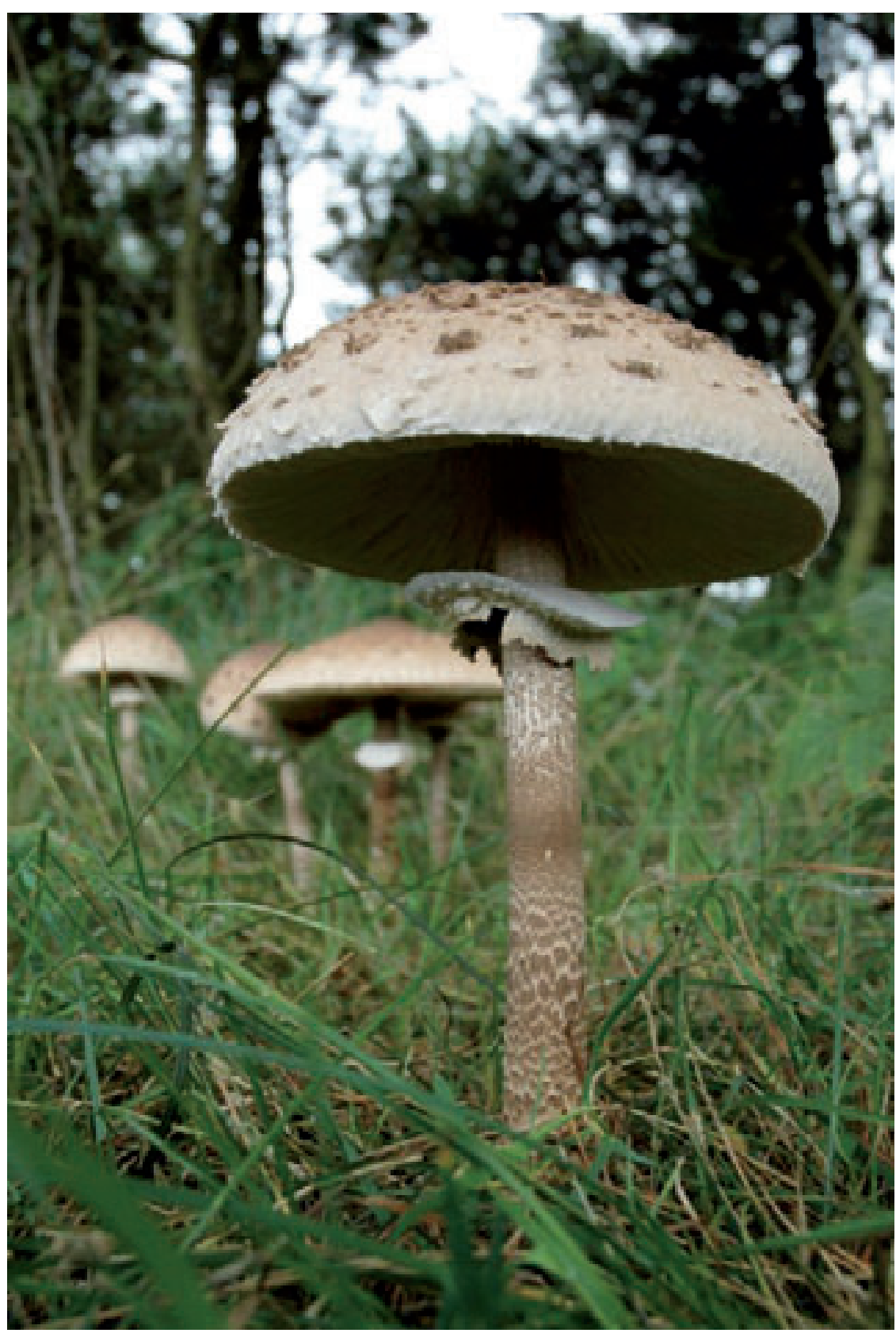

Biodiversiteetti käsittää kaikki eliöryhmät ja niiden elinympäristöt (kuva: Carsten Brandt). 


\title{
CITES-sopimus
}

\section{Villieläimistön ja -kasviston uhanalaisten lajien kansainvälistä}

\author{
kauppaa koskeva yleissopimus
}

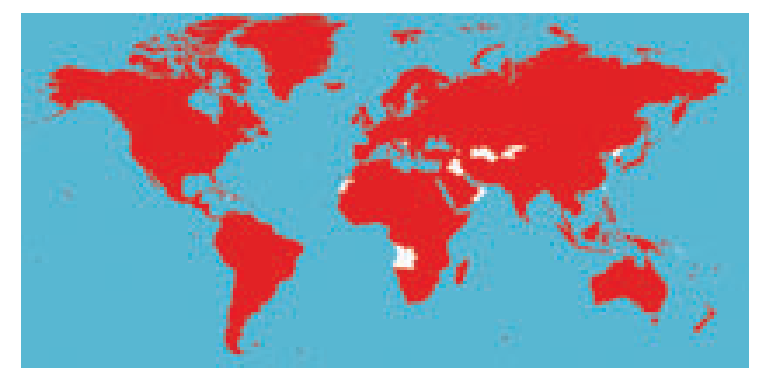

Monien luonnonvaraisten eläinlajien uhanalaisuuden syynä on pyynti lemmikkieläimeksi tai vankeudessa lisättävksi sekä eläimistä saatavien tuotteiden vuoksi. Useat kasvilajit ovat uhanalaisia keräilyn ja elinympäristön häviämisen vuoksi. Monet näistä uhanalaisista lajeista ovat lisäksi laajan kansainvälisen kaupan kohteena ja tätä taustaa vasten solmittiin CITES-sopimus vuonna 1973 (Washingtonin yleissopimus).

\section{Tarkoitus}

Yleissopimuksen tarkoituksena on suojella lajeja, jotka ovat uhanalaisia tai voivat tulla sellaisiksi kansainvälisen kaupan seurauksena. Tavoitteena on, että kaupan tulee olla kestävällä pohjalla, eli että lajien populaatioita ei hyödynnetä enemmän kuin ne kestävät.

Yleissopimuksen säännöt koskevat sekä eläviä yksilöitä noin 5000 eläinlajista ja 28 ooo kasvilajista että näistä saatavia erilaisia tuotteita, jotka mainitaan yleissopimuksen lajiliitteissä (CITES-lajit).

Yleissopimus koskee suurta määrää trooppisia lajeja, mutta myös useat pohjoismaiset lajit - esimerkiksi pöllöt, petolinnut, saukot, sudet ja jääkarhut - ovat mukana.

\section{Miten yleissopimus vaikuttaa?}

Sopimusosapuolten tulee rajoittaa uhanalaisten eläinten ja kasvien kauppaa kieltämällä niiden maahantuonti, maastavienti ja jälleenvienti ensisijaisesti kaupallisiin tarkoituksiin. Kun on kyse vähemmän uhanalaisten lajien kaupasta, voidaan niiden maahantuonti ja maastavienti sallia lupamenettelyn kautta.

CITES-sopimuksen piiriin kuuluvat lajit on sijoitettu 3 lajiliitteeseen niiden uhanalaisuuden mukaan (Laatikko 1).

Yli 1000 eläin-tai kasvilajia on niin uhanalaisia, että niiden kauppaaminen on täysin kielletty (liite I). Muille lajeille maastaviennille vaaditaan aina sopimuksenmukainen vientilupa tai -todistus (liitteet II ja III). Jotkin maat asettavat myös näiden lajien maahantuonnille rajoituksia.

\section{Erityiset tuontirajoitukset EU- alueelle}

EU on asettanut CITES-sopimusta tiukemmat säännöt uhanalaisten lajien maahantuonnille ja viennille omalla EU-lainsäädännöllä. Joissakin tilanteissa on myös erityisiä rajoituksia EU:n sisällä tapahtuvalle kaupalle. Lajit, joita EU:n säännöt koskevat, on sijoitettu EU:n asetuksen yleissopimuksen neliään lajiliitteeseen (Laatikko 2).
Laatikko 1:

Liite I: Lajit, joilla ei saa käydä kauppaa. Lajeja pidetään kaikkein uhanalaisimpina.

Liite II: Lajit, joiden tuontia ja vientiä säännöstellään lajien kantojen turvaamiseksi.

Liite III: Lajit, joiden tuontia ja vientiä säännöstellään, mikäli ne tulevat määrätyistä maista. 


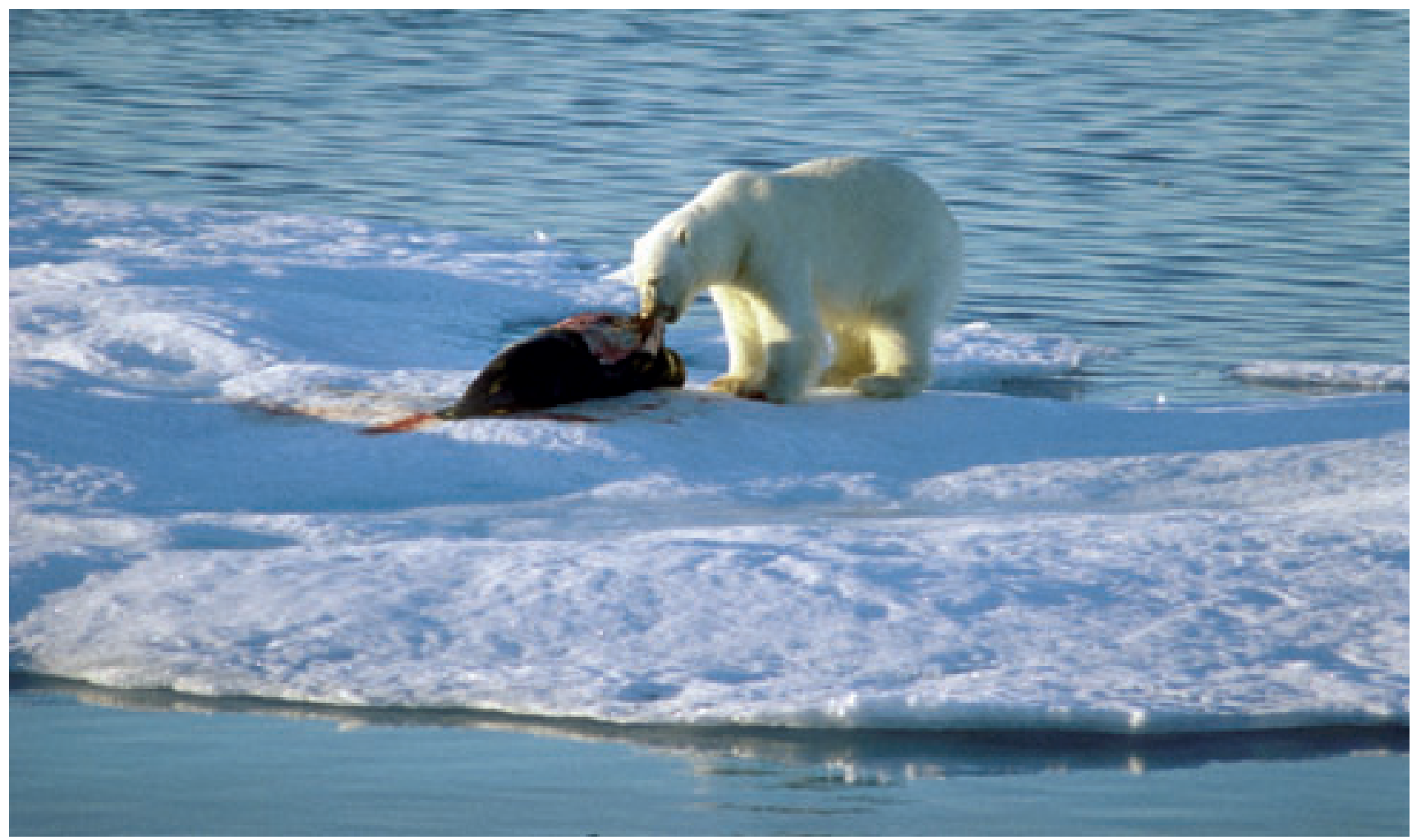

Jääkarhu on yksi pohjoismaisista lajeista, joka kuuluu CITES-sopimuksen piiriin. Jääkarhuja (Ursus maritimus) on metsästetty monia vuosia mm. niiden nahkojen vuoksi (kuva: John Frikke).

Laatikko 2:

Liite A: CITES-sopimuksen liitteessä I olevat lajit sekä liitteissä II ja III olevat lajit, joita EU haluaa kohdella kuin kuuluisivat sopimuksen liitteeseen I. Liitteeseen kuuluvat myös lajit, joita sopimus ei suojele, mutta jotka kuuluvat muun EU-lainsäädännön alaisuuteen. Niiden sopimuksen määräysten lisäksi, jotka koskevat lajeja liitteessä I:ssä, on olemassa erityisiä EU-lainsäädäntöön perustuvia rajoituksia, jotka liittyvät EU:n rajojen sisällä käytävään kauppaan.

Liite B: Ensisijaisesti CITES-sopimuksen liitteen II:n lajit sekä muutama liitteen III:n lajeista. Liitteessä on myös lajeja, jotka eivät kuulu sopimukseen, mutta joiden katsotaan muodostavan ekologisen uhan EU-alueen luontaiselle eliöstölle. Niiden kauppa voidaan sallia tiukennetuin määräyksin.

Liite C: CITES-sopimuksen liitteen III:n lajit. Siinä pätevät samat ohjeet kuin liitteen III:n kohdalla, mutta lisäksi vaaditaan EU:n alueelle tapahtuvassa tuonnissa tuonti-ilmoitus.

Liite D: CITES-sopimuksen III-liitteen lajit, joiden osalta EU on tehnyt varauman. Lisäksi on otettu mukaan sopimukseen liitteen ulkopuolelta lajeja, joiden tuontia halutaan seurata. Tuonti EU:hun vaatii tuonti-ilmoituksen.

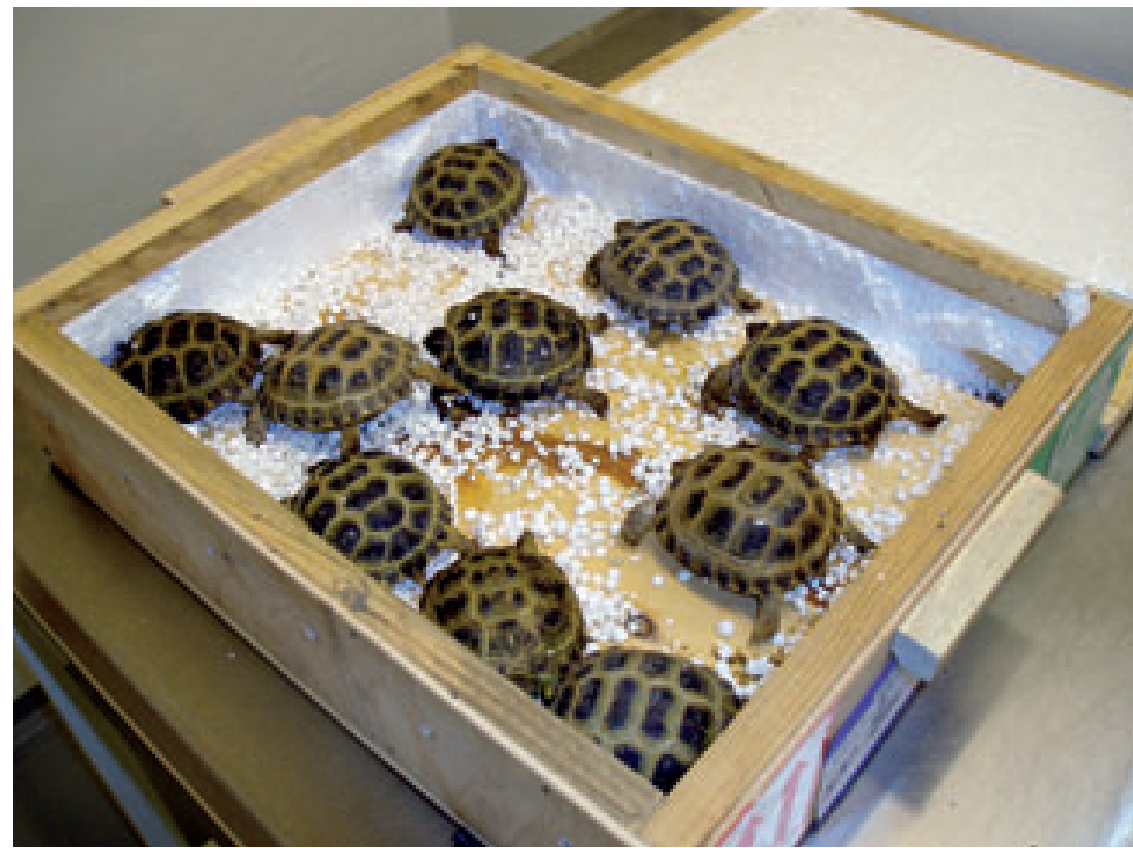

Joka vuosi miljoonia eläviä eläimiä ja kasveja myydään ympäri maailmaa lemmikkieläimiksi ja koriste- ja huonekasveiksi (kuva: Skov- og Naturstyrelsen). 


\section{Ramsarin yleissopimus \\ Vesilintujen elinympäristönä kansainvälisesti merkittäviä \\ vesiperäisiä maita koskeva yleissopimus}

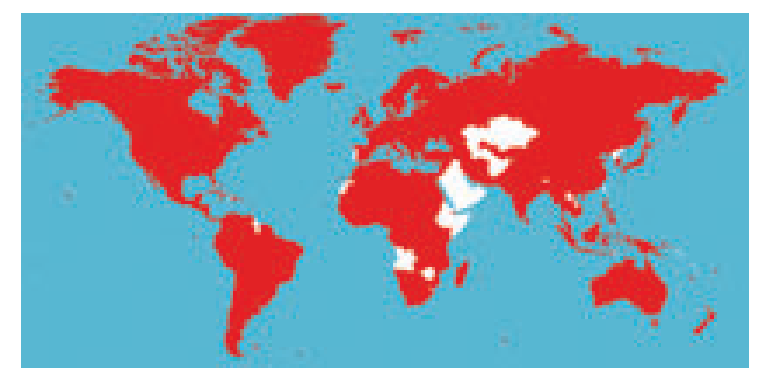

Vuonna 1971 solmittiin "Vesilintujen elinympäristönä kansainvälisesti merkittäviä vesiperäisiä maita koskeva yleissopimus”. Nykyään yleissopimusta kutsutaan yksinkertaisesti vain Ramsarin yleissopimukseksi.

Yleissopimus astui voimaan vuonna 1975 ja tällä hetkellä yleissopimuksen on allekirjoittanut 152 maata, mm. kaikki Pohjoismaat. Yleissopimus käsittää kaikkiaan 1629 kosteikkoaluetta, joilla on kansainvälisesti merkitystä vesilinnuille.

\section{Tarkoitus}

Yleissopimuksen tarkoituksena on suojella varsinkin vesilintujen elinympäristönä merkittäviä kosteikkoalueita. Kaikkia alueita, jotka ovat kansainvälisesti merkittäviä vesilinnuille, on suojeltava. Alueen voidaan katsoa olevan kansainvälisesti merkittävä, jos alueella tavataan usein yli 20000 lajiyksilöä tai jos alueella tavataan vähintään $1 \%$ lajin tai sen alalajin populaatiosta.

Yleissopimus ei koske vain vesilintuja, vaan alueen kaikkia eläin- ja kasvilajeja on suojeltava liialliselta hyväksikäytöltä luonnollisen ympäristön suojelemiseksi.

\section{Ramsar-alueet}

Kosteikot tarkoittavat eri luontotyyppejä, jotka muodostavat maan ja veden välisen rajavyöhykkeen. Ramsarin yleissopimuksen määritelmä kosteikoista on hyvin laaja. Se käsittää mm. rannat sekä niiden läheiset tulva- ja tuoreet niityt, lahdelmat, suot ja järvet sekä murtovedet ja suolaiset vedet, joiden syvyys laskuveden aikana ei ylitä kuutta metriä.

Alueet eivät ole ainostaan tärkeitä linnuille, vaan niillä on merkitystä myös muulle eläimistölle. Alueet voivat olla esimerkiksi tärkeitä kalojen kutu- ja kasvupaikkoja.

\section{Velvoitteet}

Yleissopimukseen liittyneet maat sitoutuvat osoittamaan vähintään yhden Ramsar-alueen ja työskentelemään yleisestikin kosteikkojen turvaamiseksi. Kosteikkoalueiden hyödyntämisen on tapahduttava kestävällä tavalla. Tämä tarkoitta sitä, että alueiden hallinnon on sekä huolehdittava alueen laadusta että varmistettava, että alueen virkistyskäyttö ei heikennä alueen arvoja. Jäsenmaat sitoutuvat myös edistämään kosteikkojen ja vesilintujen suojelua perustamalla suojelualueita, ja maiden on tehtävä yhteistyötä suojellakseen elinympäristöjä ja lajeja yhteisillä kosteikkoalueillaan.

\section{Pohjoismaiden Ramsar-alueet} Pohjoismaissa on erityisen paljon kosteikkoalueita. Tämä koskee erityisesti Suomea ja Ruotsia, joissa on paljon suoalueita ja matalavetisiä järviä. Ramsarin yleissopimuksen määritelmän mukaan 25 \% Suomen ja Ruotsin alueista on kosteikkoalueita.

Pohjoismaat olivat osoittaneet 24.4.2006 yhteensä 178 aluetta, pinta-alaltaan 35682 ha, Ramsaralueiksi. Alueiden määrä ja laajuus osoittavat, että Pohjoismaiden kosteikkoalueilla on suuri merkitys monille vesilinnuille. 


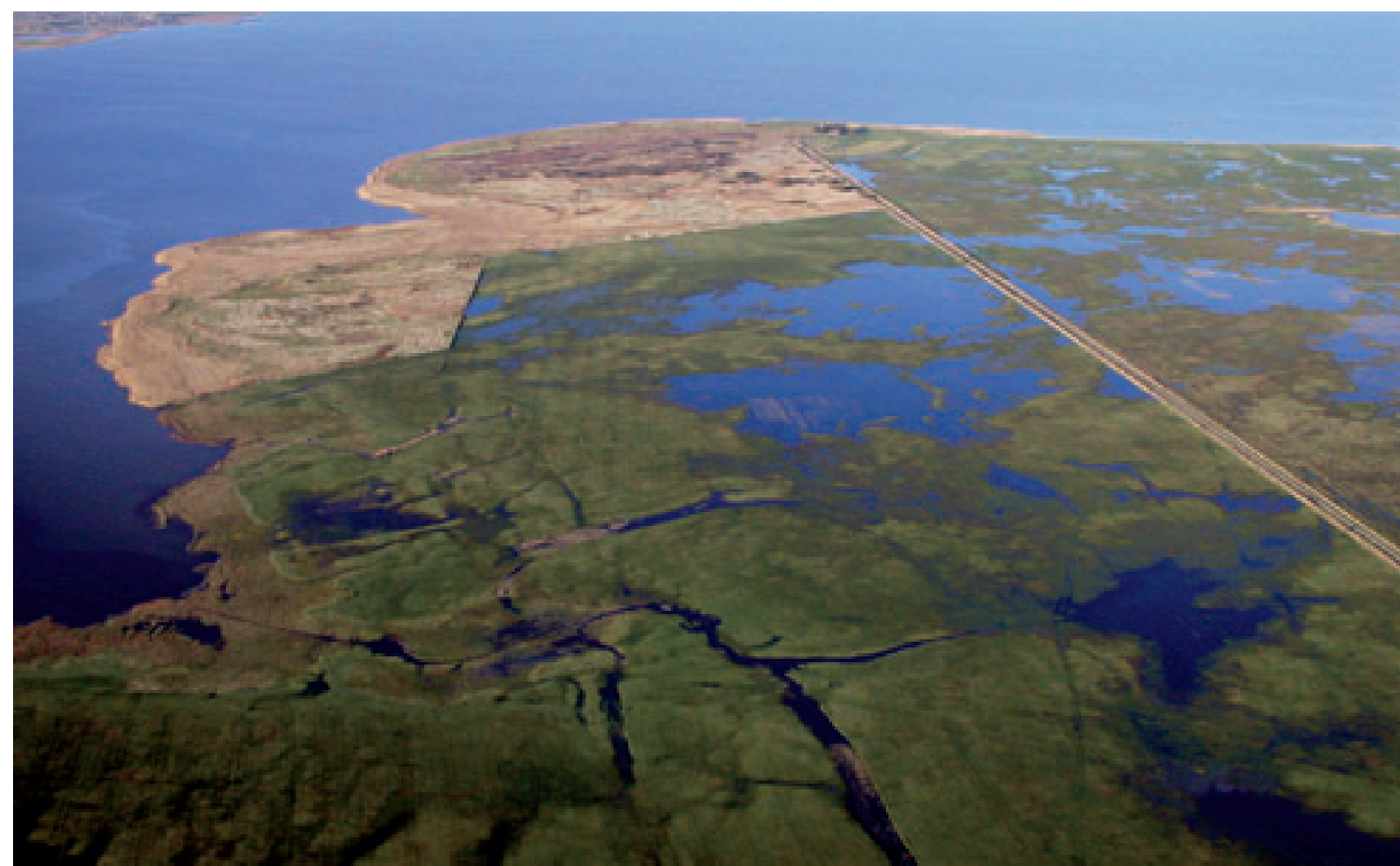

Maat, jotka ovat liittyneet Ramsarin sopimukseen, ovat velvollisia osoittamaan vähintään yhden Ramsar-alueen sekä edistämään kosteikkoalueiden suojelua mm. perustamalla suojelualueita. Ringkøbing-vuonon niemenkärjet ovat yksi Tanskaan perustetuista kosteikkojen suojelualueista (kuva: Jens Muff Hansen/Naturplan).

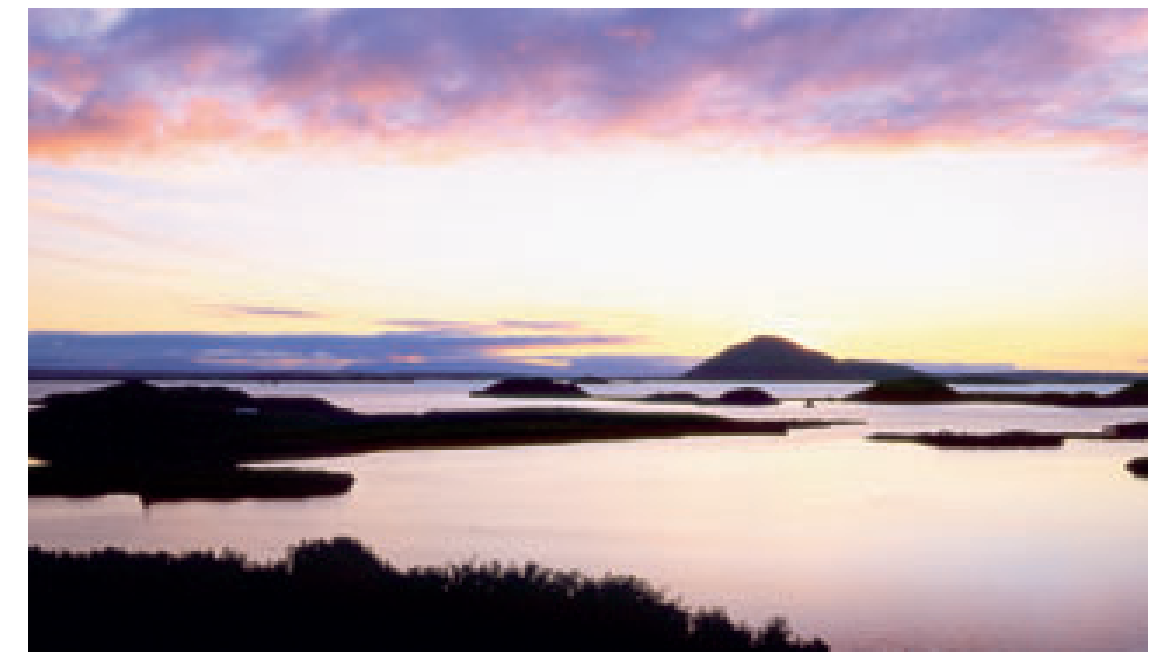

Myvatn Islannissa on alue, jolla on kansainvälistä merkitystä vesilinnuille (kuva: Arni Einarsson). 


\section{Bernin yleissopimus}

\section{Yleissopimus Euroopan luonnonvaraisen kasviston ja eläimistön sekä niiden elinympäristön suojelusta}

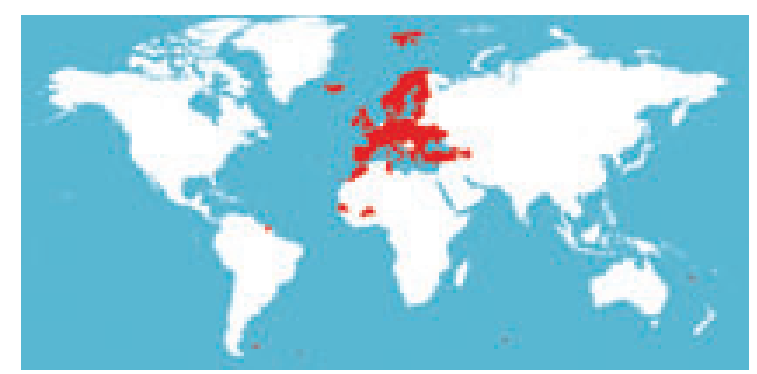

Bernin yleissopimus, joka hyväksyttiin 1979, koskee Euroopan luonnonvaraisten eläinten, kasvien ja niiden elinympäristöjen suojelua. EU ja 45 Euroopan ja Afrikan valtiota ovat mukana yleissopimuksessa. Sen lisäksi sopimuksen mukaiseen toimintaan osallistuu muutamia valtioita tarkkailijoina.

\section{Kaikki Pohjoismaat Grönlantia ja} Färsaaria lukuun ottamatta ovat liittyneet yleissopimukseen.

\section{Tarkoitus}

Bernin yleissopimuksen tarkoituksena on suojella eläimiä ja kasveja sekä niiden elinympäristöjä. Monia lajeja ja niiden elinympäristöjä uhkaa sukupuuttoon kuoleminen tai häviäminen taikka ne ovat vaarantuneita. Jotta voidaan varmistua siitä, että ne eivät häviä, niihin tulee kohdistaa erityisiä suojelutoimia. Myös muuttavilla lajeilla on erityisiä suojeluvaatimuksia.

Yleissopimuksen on määrä edistää - lajien ja elinympäristöjen suojelun ohella - myös eri maiden välistä yhteistyötä ja sen koordinointia. Näin sopimuksen tavoitteet voidaan täyttää yhteisesti.

\section{Miten yleissopimus toimii} Yleissopimuksen piiriin kuuluvat kasvi- ja eläinlajit on sijoitettu kolmeen liitteeseen (Laatikko I). Liitteestä ilmenee, kuinka uhanalaisia tai vaarantuneita lajit ovat.

Neljäs liite koskee pyyntimenetelmiä ja pyyntivälineitä.

Liitteessä I on lähinnä eteläeurooppalaisia kasvilajeja, mutta mukaan on otettu myös useita pohjoismaisia lajeja, muun muassa norjankeulankärki ja kultarikko.

Liite II käsittää myös monia pohjoismaisia lajeja, esimerkiksi kuningaskalastajan, pyöriäisen, suden, karhun, ja petolintuja sekä pöllöjä.

Liite III käsittää melkein kaikki eurooppalaiset nisäkkäät, linnut, matelijat ja sammakkoeläimet sekä muutamia kalalajeja, jotka eivät ole liitteessä II. Muun muassa majava on liitteessä III.

\section{Hallinto}

Yleissopimusta hallinnoi komitea, jossa on edustajia jäsenmaista ja tarkkailijamaista. Komitean tulee varmistaa, että maat noudattavat sopimuksen määräyksiä. Sen tulee myös ehdottaa, miten määräyksiä voidaan soveltaa maiden lainsäädännössä.

Kansalaisjärjestöillä (NGOt) on edustus komiteassa. Niillä on tärkeä tehtävä, koska ne usein ensimmäisinä reagoivat suojelun tai valvonnan puutteisiin.

Bernin yleissopimus on osaltaan vaikuttanut siihen, että useimmat sammakkoeläimet ja matelijalajit ovat Pohjoismaissa rauhoitettuja. 


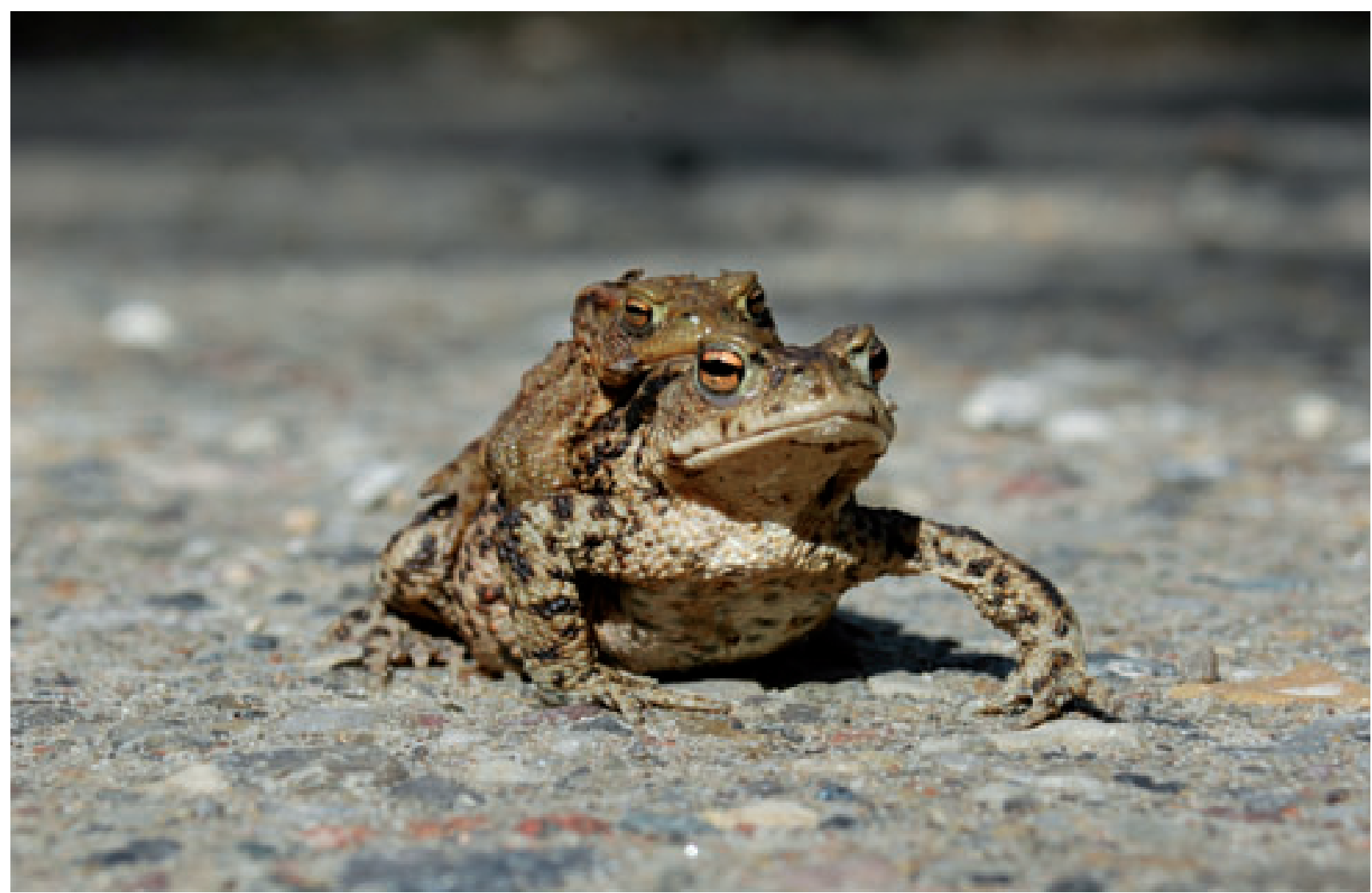

Rupisammakko (Bufo bufo) kuuluu sopimuksen liitteen III lajeihin. Liitteessä mainittujen lajien pyyntiä ja tappamista säädellään. Kaikki sammakkoeläimet kuuluvat liitteen III lajeihin, mikäli ne eivät jo ole sopimuksen liitteessä II. (kuva: Birthe Overgaard/Naturplan).

\section{Laatikko I:}

Liite I: Tiukasti suojeltavat kasvilajit. Lajit ovat niin uhanalaisia, että jäsenmaat ovat sitoutuneet varmistamaan, että näihin lajeihin ja niiden kasvupaikkoihin kohdistuu erityisiä suojelutoimia.

Liite II: Tiukasti suojeltavat eläinlajit. Maiden tulee suojella eläimiä ja niiden elinympäristöjä esimerkiksi metsästykseltä, keräilyltä, häirinnältä sekä lajien kauppaamiselta ja elinympäristön tahalliselta hävittämiseltä, mikäli näillä toiminnoilla on merkitystä niiden säilymisen kannalta.

Liite III: Lajit, joiden pyyntiä ja metsästystä tulee säädellä. Melkein kaikki lajit, jotka eivät ole liitteessä II, ovat liitteessä III. Edellytyksenä on, että lajien hyödyntämistä säädellään niin, että niiden kannat eivät vaarannu.

Liite IV: Kielletyt pyyntivälineet ja metsästysmenetelmät. Kiellettyä on muun muassa käyttää metsästyksessä puoli- tai täysautomaattisia aseita, joiden makasiiniin mahtuu enemmän kuin kaksi panosta, ansojen käyttö nisäkkäiden pyynnissä ja myrkkysyöttien käyttäminen.

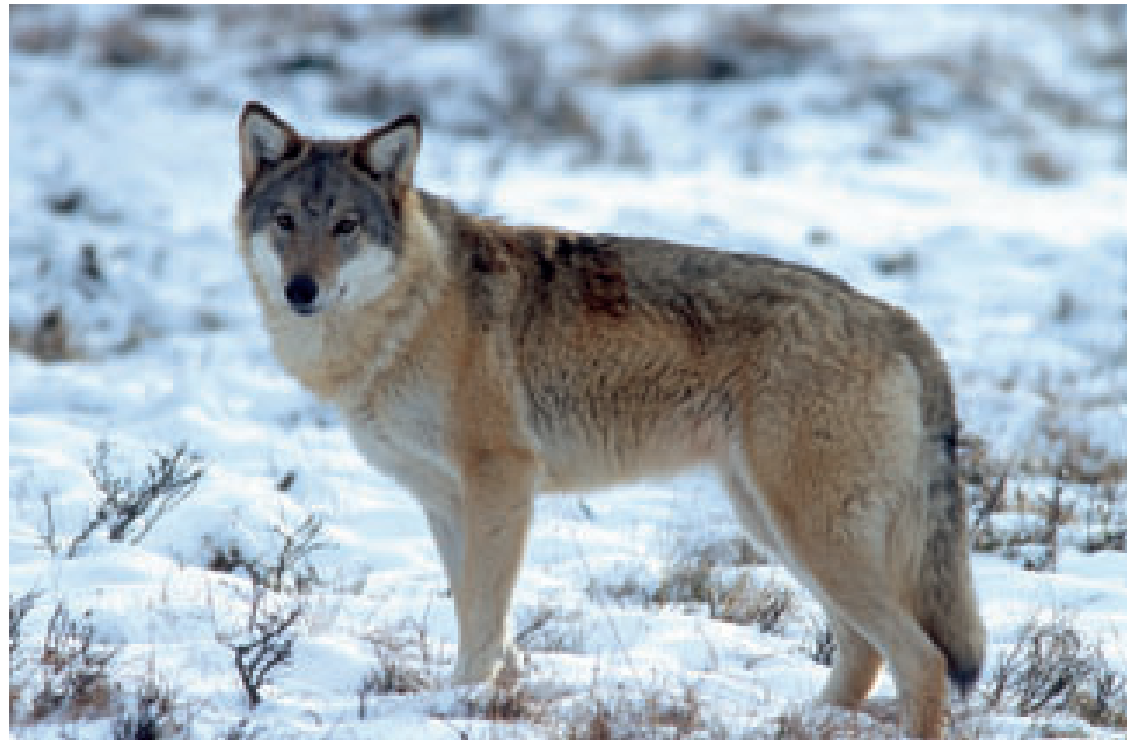

Eräät lajit ovat niin uhanalaisia, että jäsenmaat ovat velvollisisa panostamaan erityisen paljon sekä niiden että niiden elinympäristöjen suojelemiseksi. Yksi tällaisista lajeista on susi (Canis lupus) (kuva: Baard Næss/NN/Samfoto). www.conventions.coe.int CETS No.: 104 


\section{Bonnin yleissopimus}

Muuttavia luonnonvaraisia eläinlajeja koskeva yleissopimus

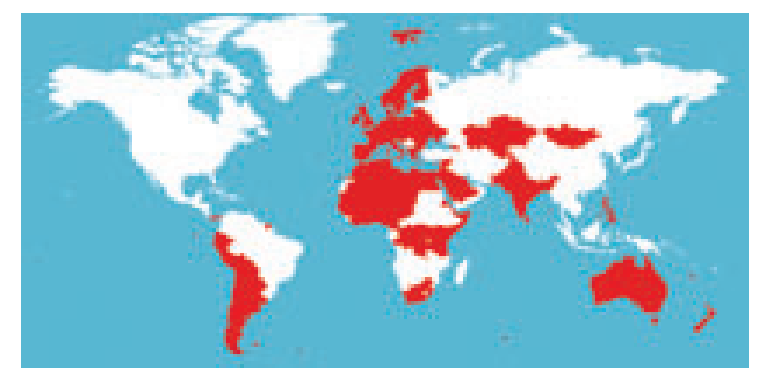

Monet eläimet ylittävät säännöllisesti maiden rajoja liikkuessaan lisääntymis- ja talvehtimispaikkojensa välillä tai etsiessään ravintoa. Tällaista tapahtuu sekä muuttolintujen, valaiden, kalojen että muiden eläinryhmien kohdalla.

\section{Tavoite}

Sopimuksen tavoitteena on suojella luonnonvaraisina eläviä eläimiä, jotka ylittävät säännöllisesti maiden rajoja. Jäsenmaat ovat velvolliset suojelemaan uhanalaisia eläinlajeja ja solmimaan alueellisia suojelusopimuksia, joilla varmistetaan, että eläimet saavat parempaa suojelua muutto- ja vaellusreiteillään. Tavoitteena on turvata lajien suotuisa suojelutaso.

\section{Lajiliitteet}

Muuttavista eläinlajeista on laadittu kaksi lajiliitettä (Laatikko 1).

\section{Liitteen I lajeihin kohdistuvat erityiset suojelutoimet}

Jäsenmaat ovat velvolliset kiinnittämään erityistä huomiota luettelon I lajeihin. Maiden tulee suojella lajien elinympäristöjä ja parantaa tai ennallistaa niiden muuton- ja talvehtimisen aikana tarvitsemia alueita. Käytännössä suojelu tarkoittaa usein sitä, että joku laji ja/tai sen kannalta merkittävä alue rauhoitetaan.

Sen lisäksi jäsenmaiden tulee pyrkiä puuttumaan niihin syihin tai toimintoihin, joiden takia lajia on uhkaamassa sukupuuttoon kuoleminen. Tämä voi koskea esimerkiksi metsästystä ja kalastusta.

\section{Liitteen II lajeja koskeva yhteistyö}

Liitteeseen II otettujen lajien suhteen voidaan tehdä kahta tarkoitusta varten alueellisia suojelusopimuksia. Ensimmäisen sopimustyypin on tarkoitus käsittää kaikki eläinlajin levinneisyysalueen maat. Sopimukset koskevat myös maita, jotka eivät ole liittyneet itse Bonnin sopimukseen.

Toinen sopimustyyppi koskee eläinlajeja, jotka ylittävät maiden rajoja vain silloin tällöin, mutta jotka kuitenkin hyötyvät kansainvälisistä suojelutoimista. Näiden sopimusten ei tarvitse välttämättä käsittää kaikkia lajin levinneisyysalueen maita.

\section{Esimerkkejä liitteisiin otetuista lajeista}

Lajiliitteeseen I on otettu yli 100 lajia, kun taas liitteessä II on yli 1000 lajia. Esimerkkejä liitteen I lajeista ovat ruisrääkkä, merikotka, ryhävalas ja grönlanninvalas. Kaskelotti, kirjohylje ja kaakkuri ovat liitteen II lajeja.

Sopimukseen on liittynyt 92 maata mukaan lukien Pohjoismaat paitsi Islanti

Boks 1:

Lajiliite I: Lajit, joita uhkaa sukupuuttoon kuoleminen niiden koko levinneisyysalueella tai sen osalla.

Lajiliite II: Lajit, jotka tarvitsevat tai hyötyvät valtioiden välisistä alueellisista sopimuksista. 


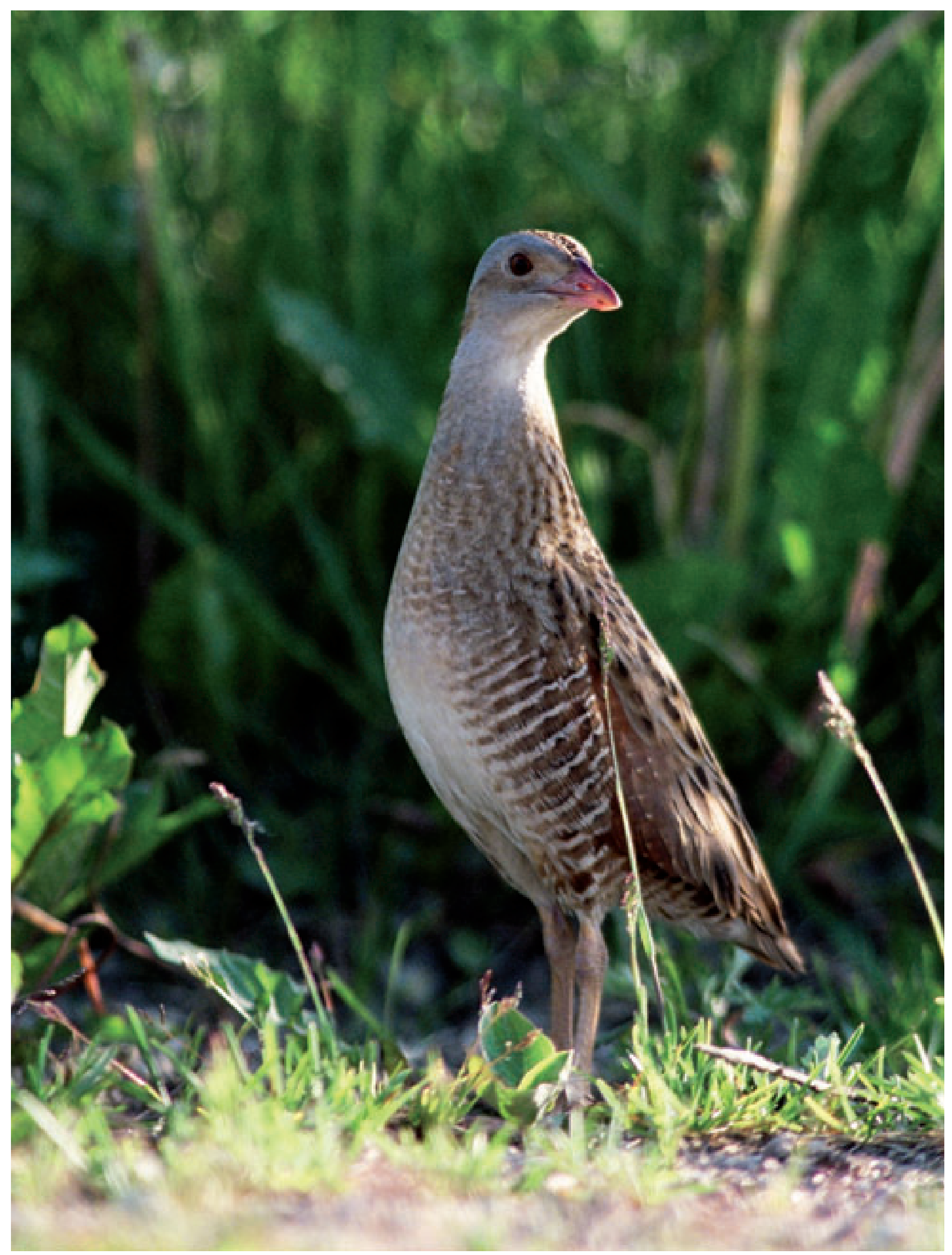

Ruisrääkkä (Crex crex) on uhanalainen koko levinneisyysalueellaan ja se on otettu mukaan Bonnin sopimuksen liitteeseen I. Useilla alueilla on käynnistetty hankkeita, joiden tarkoituksena on luoda uusia tai säilyttää nykyisiä elinympäristöjä (kuva: Aivars Petrins/Naturplan). 


\section{Kansainväliset alueelliset sopimukset}

AEWA, EUROBATS ja ASCOBANS

ovat laajimpia Bonnin sopimuksen

alaisia alueellisia sopimuksia.

\section{AEWA (African-Eurasian Waterbird Agreement)}

Afrikan ja Euraasian muuttavien vesilintujen suojelua koskevan sopimuksen eli AEWA:n tarkoituksena on suojella nimensä mukaisesti vesilintuja, jotka muuttavat Afrikan, Euroopan ja Aasian välillä. Vesilinnut muuttavat usein pitkiä välimatkoja ja ylittävät matkallaan useiden maiden rajoja. Siksi kansainvälisellä yhteistyöllä on tarpeen varmistaa, että lintuja suojellaan mahdollisimman hyvin niiden lisääntymis- ja talvehtimispaikoilla ja niissä maissa, joiden kautta niiden muuttoreitti kulkee.

Ne maat, jotka ovat liittyneet sopimukseen, sitoutuvat esimerkiksi suojelemaan ja ennallistamaan vesilintujen elinympäristöjä sekä käynnistämään tutkimushankkeita, joilla voidaan luoda linnuille paremmat elinolosuhteet.

Sopimus koskee 235 vesilintulajia, jotka viettävät koko vuoden tai osan vuodesta kosteikoissa. Sopimukseen, joka kattaa koko Afrikan ja Euroopan, osia Aasiasta ja joitakin arktisia alueita, on liittynyt 53 maata mukaan lukien Tanska, Suomi ja Ruotsi.
EUROBATS (The Agreement on the Conservation of Populations of European Bats)

Sopimuksen tarkoituksena on suojella Euroopan lepakoita. Solmimalla sopimuksen maat sitoutuvat jakamaan tietoa lepakoista ja luomaan asiaankuuluvaa lainsäädäntöä sekä tekemään yhteistyötä lepakoiden suojelemiseksi myös niiden maiden kanssa, jotka eivät ole liittyneet Bonnin sopimukseen.

Useita lepakkolajeja uhkaa häviäminen sukupuuttoon sopivien elinpaikkojen menettämisen takia. Huonontuneet olosuhteet johtuvat muun muassa torjunta-aineiden käytöstä ja lepakkojen biologian ja elinpaikkojen riittämättömästä tuntemuksesta.

Sopimus käsittää kaikki 45 eurooppalaista lepakkolajia.

Sopimukseen on liittynyt 48 maata mukaan lukien Tanska, Suomi, Norja ja Ruotsi.

\section{ASCOBANS (Agreement on the Conservation of Small Cetaceans of the Baltic and North Seas) \\ ASCOBANS:in tarkoituksena on} suojella Itämeren ja Pohjanmeren pieniä hammasvalaita. Kaikki ham- masvalaat kaskelottia lukuun ottamatta ovat mukana sopimuksessa. Sopimukseen liittyneet maat ovat velvolliset suojelemaan valaitaan panemalla toimeen erilaisia tutkimus- ja suojeluhankkeita.

Tällä hetkellä sopimuksen jäseninä ovat seuraavat maat: Belgia, Tanska, Suomi, Ranska, Saksa, Liettua, Hollanti, Puola, Ruotsi ja Iso-Britannia.

Vastaavanlainen sopimus, ACCOBAMS, on solmittu Välimeren ja sen lähivesien hammasvalaiden osalta.

Lähempiä tietoja näistä kolmesta yhteistyösopimuksesta:

http://www.unep-aewa.org/ http://www.ascobans.org/ http://www.eurobats.org/ 


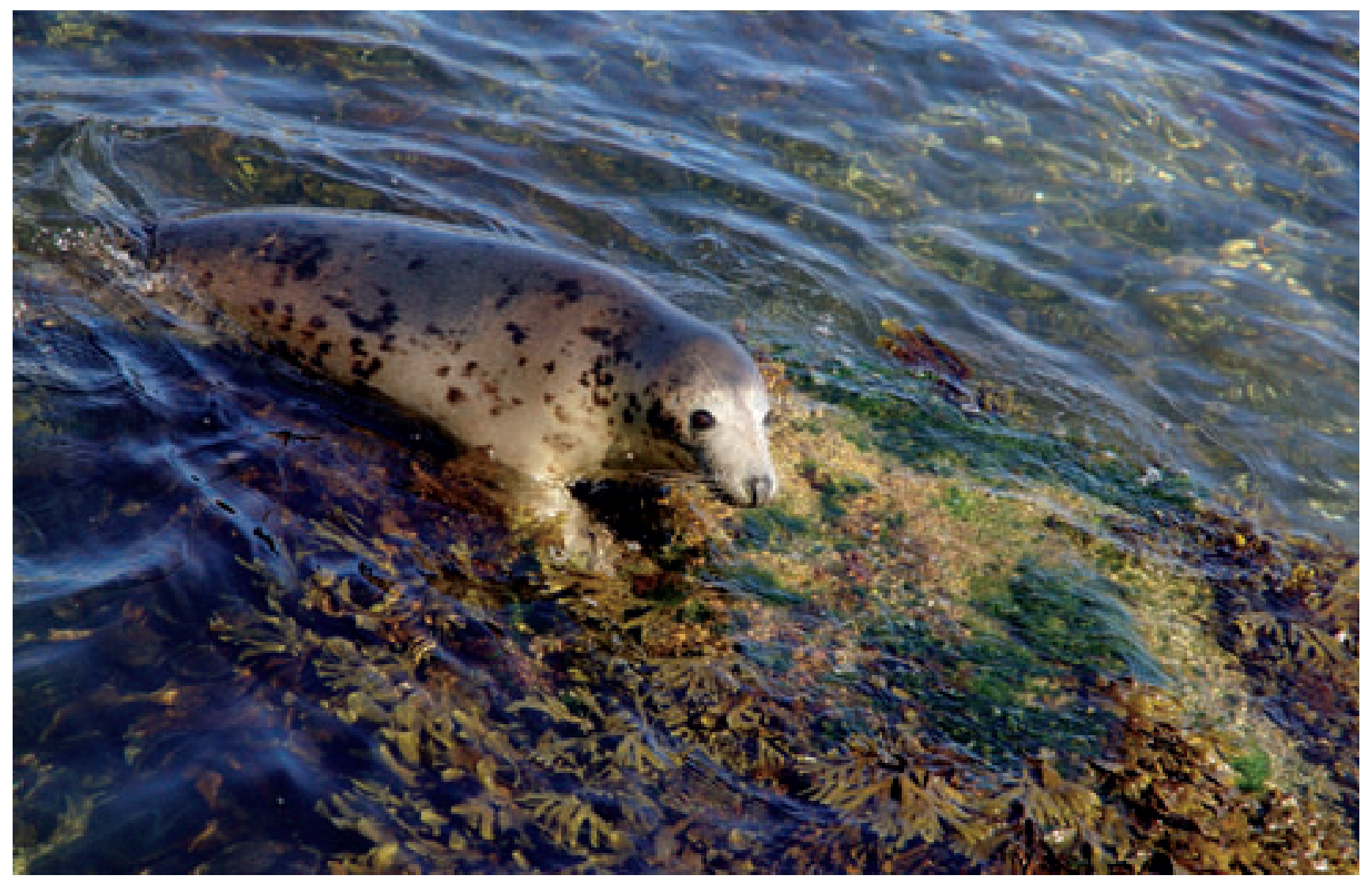

Kirjohylje (Phoca vitulina) on otettu sopimuksen luetteloon II. Saksa, Hollanti ja Tanska ovat solmineet sopimuksen hylkeiden suojelemiseksi Vattimeren alueella. Sopimuksen tavoitteena on luoda hyvät elinolosuhteet, jotta hyljekanta pysyy terveenä ja elinvoimaisena (kuva: Stig Bachmann Nielsen/Naturplan).

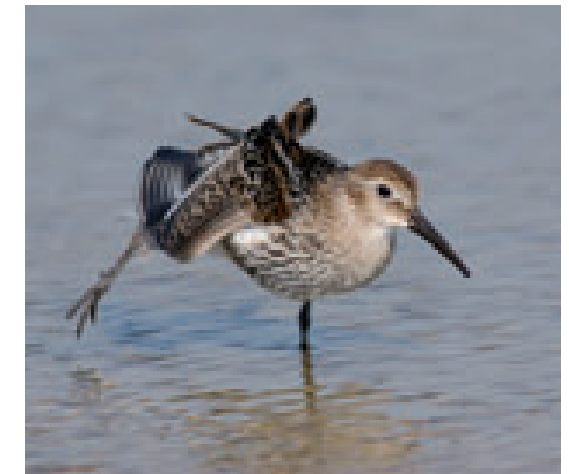

Suosirri (Calidris alpina) on yksi niistä 235:stä Afrikan, Aasian ja Euroopan välillä muuttavasta lintulajista, jotka kuuluvat yleissopimuksen piiriin (kuva: Klaus Mortensen/Naturplan).

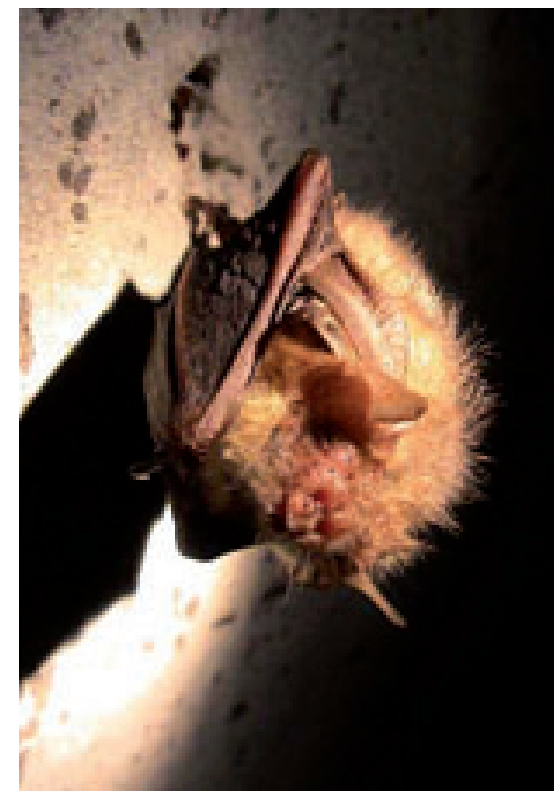

EUROBATS on 48:n maan välillä solmittu alueellinen suojelusopimus. Sopimuksen tarkoituksena on parantaa yleisesti lepakkojen elinoloja (kuva: Andis Liepa) Naturplan). 


\section{Valaanpyyntisopimus}

\section{Valaanpyynnin säätelyä koskeva kansainvälinen yleissopimus}

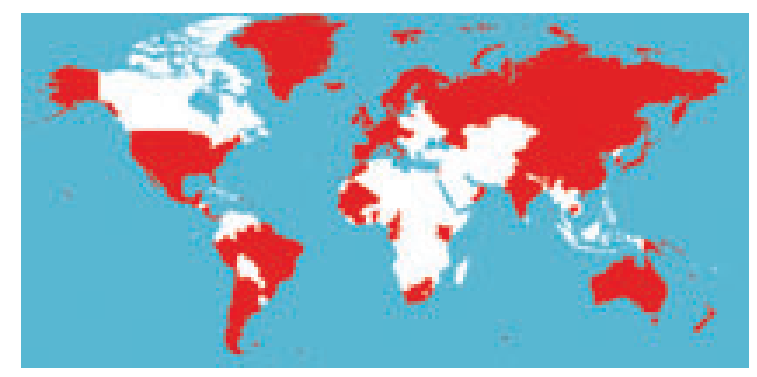

1930-luvulla useat valtiot harjoittivat niin tehokasta valaanpyyntiä, että se oli johtaa valaiden kuolemiseen sukupuuttoon. Valaskannan suojelemiseksi Norja ja Englanti solmivat jo 1931 sopimuksen valaanpyynnin rajoittamisesta. Vuonna 1937 muitakin maita tuli mukaan sopimukseen, joka ei kuitenkaan ollut erityisen tehokas, sillä uusia valaanpyyntivaltioita nousi jatkuvasti esiin. Uudet säännökset olivat siis tarpeen ja siksi 15 valaanpyyntivaltiota laativat Valaanpyynnin säätelyä koskevan kansainvälisen yleissopimuksen vuonna 1946. 1970-luvun lopussa ja 1980-luvun alussa yleissopimuksen sisältöä muutettiin uusien maiden allekirjoittaessa yleissopimuksen. Useimmat uudet jäsenmaat toimivat pääsääntöisesti valaanpyynnin lopettamiseksi tai sen rajoittamiseksi merkittävästi.

\section{Tarkoitus}

Yleissopimuksen tarkoituksena on suurten valaiden hoito ja suojelu. Tämä toteutetaan mm. säätelemällä suurten valaiden pyyntiä.

\section{Yleissopimuksen hallinnointi} Valaanpyyntisopimusta hallinnoi Kansainvälinen valaanpyyntikomissio, joka päättää pyyntikiintiöistä tieteellisten tutkimusten pohjalta. Päätökset tehdään mm. arvioimalla valaskantojen kokoa ja valaiden lisääntymistä sekä tutkimalla valaiden terveydentilaa, ympäristön saastumista, kalastuksen sivusaaliita, ilmastonmuutoksia, erilaisia häiriöitä ja laivaliikennettä.

\section{Pyyntikielto} 1986 astui voimaan Valaanpyyntikomission pyyntikielto, joka koski suurten valaslajien pyyntiä muuhun kuin tieteelliseen tarkoitukseen. Kiellon oli tarkoitus olla voimassa 5 vuoden ajan komission tehdessä laajaa arviota valaskannoista. Kieltoa on myöhemmin pidennetty ja se on voimassa pysyvästi. Norja on vastustanut kieltoa ja harjoittaa yhä lahtivalaiden pyyntiä.

\section{Perinteiset valaanpyyntimaat}

Grönlannissa valaanpyynti käsitetään "alkuperäiskansojen perinteiseksi valaanpyynniksi" ja siten Grönlannin eskimoilla on pysyvä lupa pyytää tietty määrä suuria valaita.

\section{Lajien tai alueiden rauhoittaminen}

Valaanpyyntisopimuksen mukaan rauhoittamistapoja on kaksi.

Voidaan joko rauhoittaa valaslajeja tai osoittaa maantieteellisiä alueita, joilla valaanpyynti on kielletty. Vuonna 1979 kiellettiin valaanpyynti Intian valtamerellä ja 1994 rauhoitettiin Etelämannerta ympäröivän meren valaat.

\section{Pikkuvalaat}

Sopimus ei käsitä pikkuvalaita. Pikkuvalaiden suojelu sisältyy CITESsopimukseen, Bernin yleissopimukseen ja Bonnin yleissopimukseen.

\section{Jäsenet}

Valaanpyyntisopimuksen ovat allekirjoittaneet 70 maata, joista enemmistö ei itse harjoita mitään valaanpyynnin muotoa. Kaikki Pohjoismaat ovat allekirjoittaneet Valaanpyyntisopimuksen. 


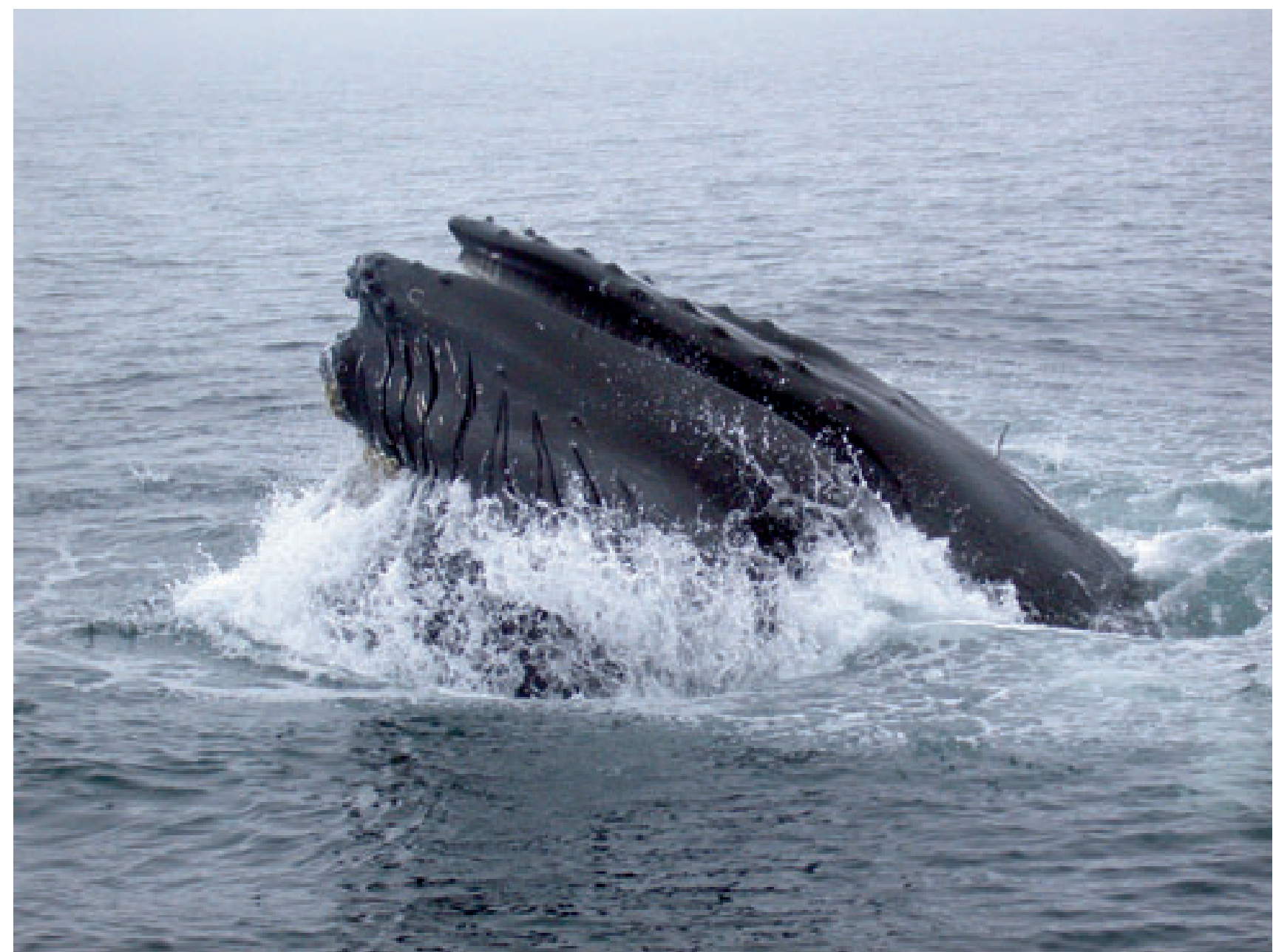

Vuosikymmenien ajan jatkunut pyynti oli johtanut suurvalaiden kantojen pienenemiseen, jonka seurauksena Valaanpyyntikomissio päätti kaupallisen valaanpyynnin kieltämisestä. Pyyntikielto koskee ryhävalasta (Megaptera novaeangliae) (kuva: Jens Muff Hansen/Naturplan).

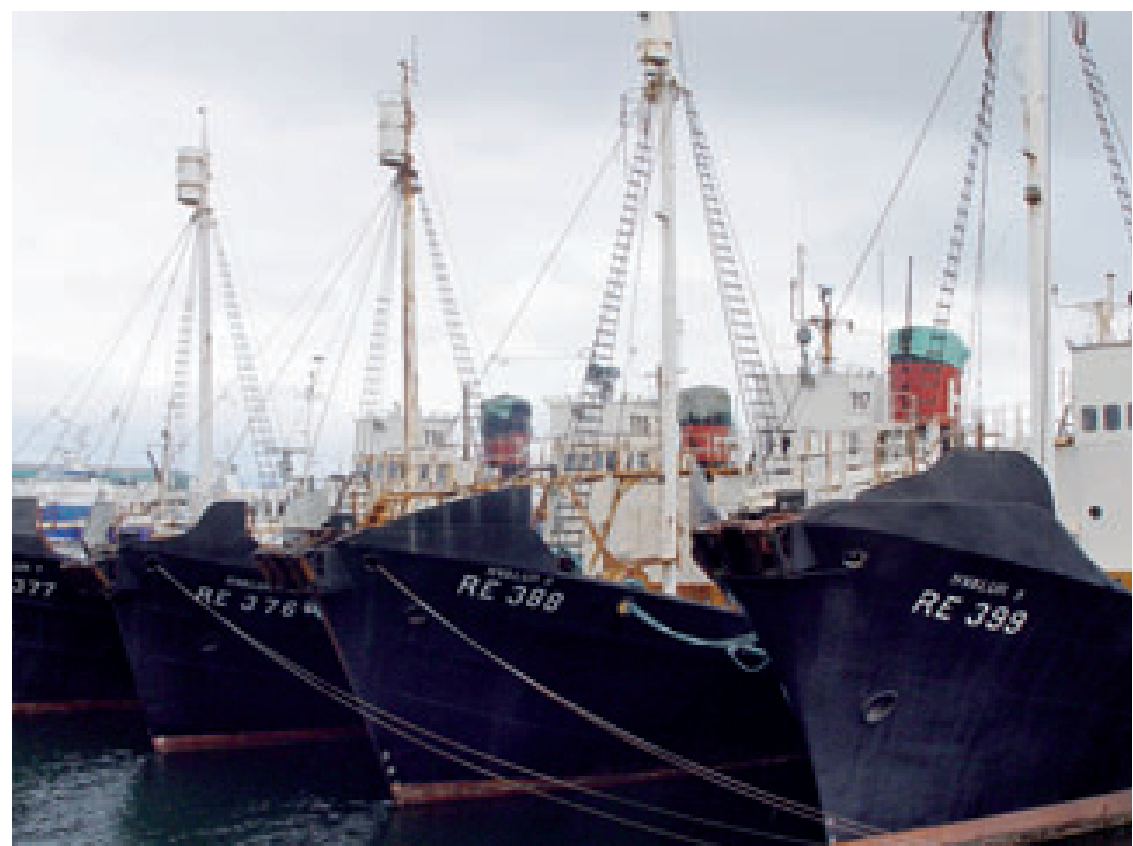

Valaanpyyntialuksia Reykjavikin satamassa (kuva: Torben Christensen/Scanpix). 


\section{Helsingin yleissopimus}

Itämeren alueen merellisen ympäristön suojelua

koskeva yleissopimus

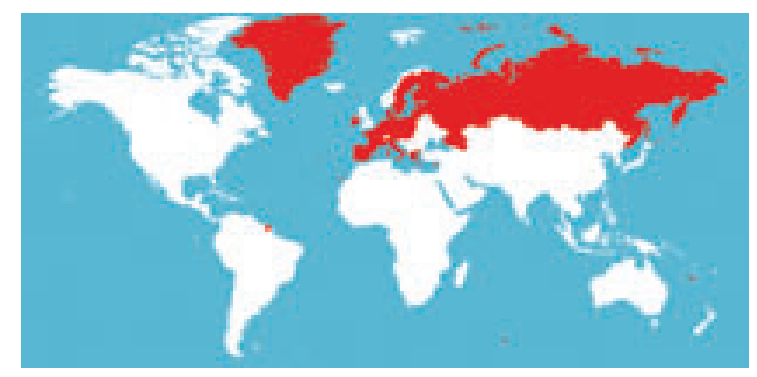

Ravinteiden ja ympäristölle vieraiden aineiden päästöt vesistöön sekä ylikalastus ja kasvava laivaliikenne muodostavat yhä suuremman ongelman Itämeren ympäristölle. Monet alueen lajit ovat saastumisen ja ylikalastuksen seurauksena joko kadonneet kokonaan tai uhanalaisia.

Vuonna 1974 silloiset 7 Itämeren maata laativat vuonna 1974 Helsingin yleissopimuksen Itämeren huonon tilanteen vuoksi. Sopimus oli ensimmäinen kansainvälinen yleissopimus, joka otti esille kaikki kuormituslähteet, niin maalta mereen päästöinä kulkeutuvat ravinteet ja ympäristölle vieraat aineet kuin laiva- ja lentoliikenteestä aiheutuvan saastumisen. Vuonna 1992 kaikki 9 Itämeren maata ja Euroopan talousyhteisö allekirjoittivat uuden yleissopimuksen, joka korvasi vuoden 1974 sopimuksen. Uutena asiana sopimuksessa oli biologisen monimuotoisuuden suojelu ja vuodesta 1999 lähtien on sopimus kattanut myös rannikkoalueen sekä rajat ylittävän virtaavan veden hoidon.

\section{Tarkoitus}

Yleissopimuksen tarkoituksena on pysäyttää kaikenlainen alueen saastuminen ja luoda paremmat edellytykset Itämerelle kokonaisuudessaan. Yleissopimus käsittää nykyään meren, merenpohjan ja koko Itämeren valuma-alueen ja kattaa siten kaikkiaan noin 415.000 km².

Helsingin komissio (HELCOM) Sopimuksen allekirjoittajavaltioiden edustajista muodostuvan Helsingin komission tehtävänä on varmistaa, että sopimusta sovelletaan. Komission vastuulla on ympäristön tilan valvominen ja sen tulee päätöksillään ja suosituksillaan myötävaikuttaa siihen, että päästöt Itämereen vähenevät ja sen biologinen monimuotoisuus säilyy. 1980-luvun alusta alkaen Helsingin komissio on antanut yli 200 suositusta.

Kukin maa vastaa itse suositusten ottamisesta osaksi maan lainsäädäntöä. Komissio voi tehdä päätöksen tai laatia sopimuksen vain kaikkien komission jäsenten ollessa asiasta yksimielisiä.

\section{Velvollisuudet}

Jäsenmaiden velvollisuutena on ehkäistä kaikkea saastuttamista, joka voi vahingoittaa Itämerta. Jos jokin jäsenmaista toiminnallaan saastuttaa merta, tulee maan itse maksaa saastuttamisesta seuraavat puhdistustoimet. Tämän aiheuttaja maksaa -periaatteen tarkoituksena on estää taloudellisen voiton tavoittelu johtamalla saastuttavia aineita mereen. Siten on jokaisen maan edun mukaista välttää saastuttamista, sillä puhdistustoimet aiheuttavat merkittäviä taloudellisia seurauksia.

Sen lisäksi, että jäsenmaiden tulee vähentää Itämeren saastuttamista, tulee niiden myös valvoa alueen ympäristön tilaa.

Vaikka liikakalastus on osasyynä siihen, että useat Itämeren alueen lajit ovat uhattuna, ei yleissopimus käsitä kalastusta. Kalastuksen vaikutuksia merialueella käsitellään kuitenkin yleissopimuksen määräyksissä. 


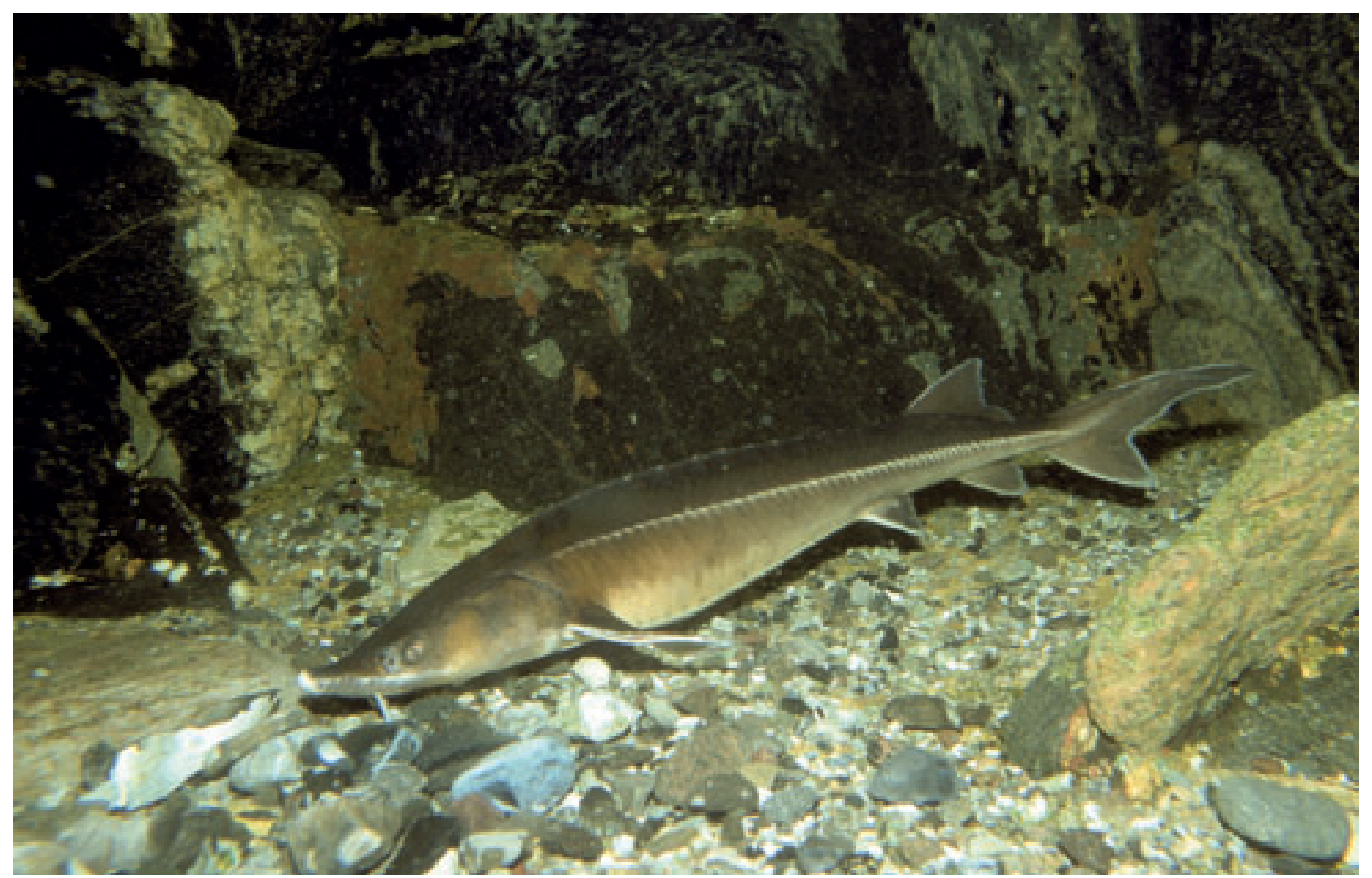

Useat Itämeren lajit ovat uhattuna johtuen saasteista ja liikakalastuksesta. Aikaisemmin alueella niin yleisesti tavattu sampi (Acipenser sturio) nyt täysin hävinnyt (kuva: Lars Laursen/Scanpix).

EU:n lisäksi sopimuksen on allekirjoittanut yhdeksän maata, eli Ruotsi, Suomi, Tanska, Viro, Latvia, Liettua, Puola, Venäjä ja Saksa.

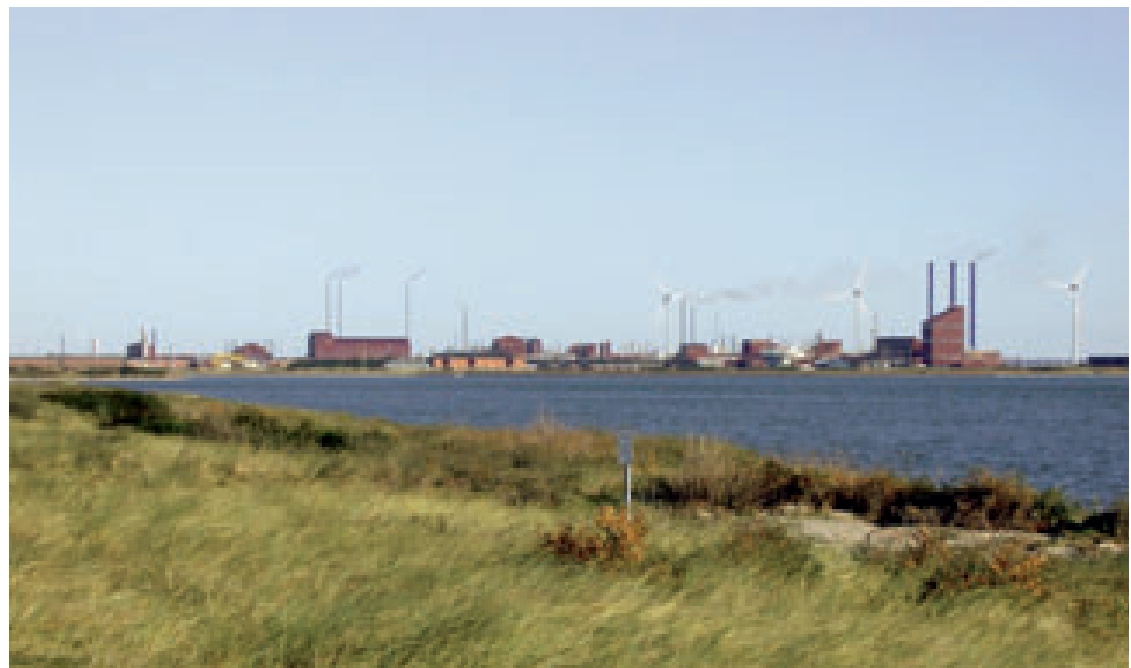

Yhtenä syynä Itämeren huonoon tilaan on ravinteiden ja ympäristölle haitallisten aineiden johtaminen mereen. Helsingin sopimus varmistaa, että ympäristölle haitallisten aineiden johtaminen mereen ei ole taloudellisesti kannattavaa (kuva: Stig Bachmann Nielsen) Naturplan). 


\section{OSPAR-sopimus}

\section{Yleissopimus Koillis-Atlantin merellisen ympäristön suojelusta}

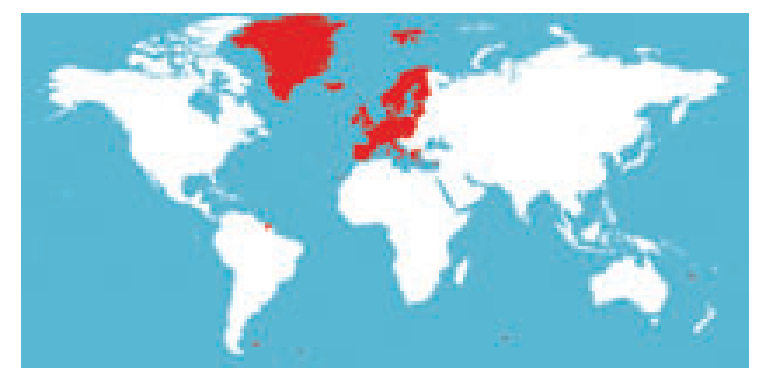

OSPAR-sopimus koskee KoillisAtlantin suojelua mukaan lukien Kattegat ja Pohjanmeri. Yleissopimus yhdistää Pariisin ja Oslon yleissopimukset, jotka käsittävät maalla sijaitsevista lähteistä tulevan saasteen ja laivasta ja lentokoneesta mereen päästettävät jätteet. Koillis-Atlantin rannikolla sijaitsevat maat olivat sitä mieltä, että kaksi muuta yleissopimusta eivät olleet riittäviä suojelemaan merta kaikilta päästön aiheuttajilta. Siksi vuonna 1992 päätettiin solmia uusi yleissopimus, jossa otetaan huomioon kaikki sellainen ihmisten toiminta, joka saastuttaa Koillis-Atlanttia.

\section{Tarkoitus}

Koillis-Atlanttia on saastutettu eri muodoissa olevilla jätteillä ja tällä on ollut valtavat seuraukset meren kasvi- ja eläinlajistolle. OSPAR-sopimuksen tarkoituksena on pysäyttää jäteaineiden johtaminen ja upottaminen mereen, jotta merialueen biologinen monimuotoisuus säilyisi ja palautuisi ennalleen.

\section{OSPAR-komissio}

OSPAR-sopimusta hallinnoi OSPAR-komissio, joka koostuu kunkin jäsenmaan edustajista. Komissio antaa ehdotuksia ja suosituksia jäsenmaille ja se on mm. kieltänyt öljyn laskemisen mereen öljynporauslautoilta ja asettanut rajoituksia radioaktiivisten aineiden ympäristöön johtamiselle. Komissio asettaa myös suurta painoa päästölähteiden ja ympäristön valvonnalle.

Komissiolla ei ole valtuuksia ottaa kantaa kalastuksen säätelyyn.

\section{Erityisen uhanalaiset elinympäristöt ja eläimet} OSPAR-komissio on toistaiseksi osoittanut 14 luontotyyppiä ja suuren määrän uhanalaisia eläinlajeja, joiden suojelemisesta jäsenmailla on erityinen vastuu. Sekä nisäkkäät, kalat, nilviäiset, matelijat että linnut ovat mukana listassa.

Esimerkkejä Pohjoismaissa sijaitsevista suojeltavista luontotyypeistä ovat ajoittain tulvivat mutamatalikot sekä ajokas- ja osteririutat.

Pohjanmeressä esiintyviin, erityistä suojelua vaativiin eläinlajeihin kuuluvat mm. purppurakotilo, sampi, sinivalas ja ruusutiira.
Yksi OSPAR-komission tarkoituksista on ylläpitää Koillis-Atlantin suojeltavien alueiden verkostoa. Komissio on määrännyt kriteerit erityistä suojelua vaativien alueiden valitsemiselle ja niiden hallinnoimiselle.

\section{Jäsenmaat}

EU:n lisäksi 15 maata on solminut sopimuksen mukaan lukien kaikki Pohjoismaat. 


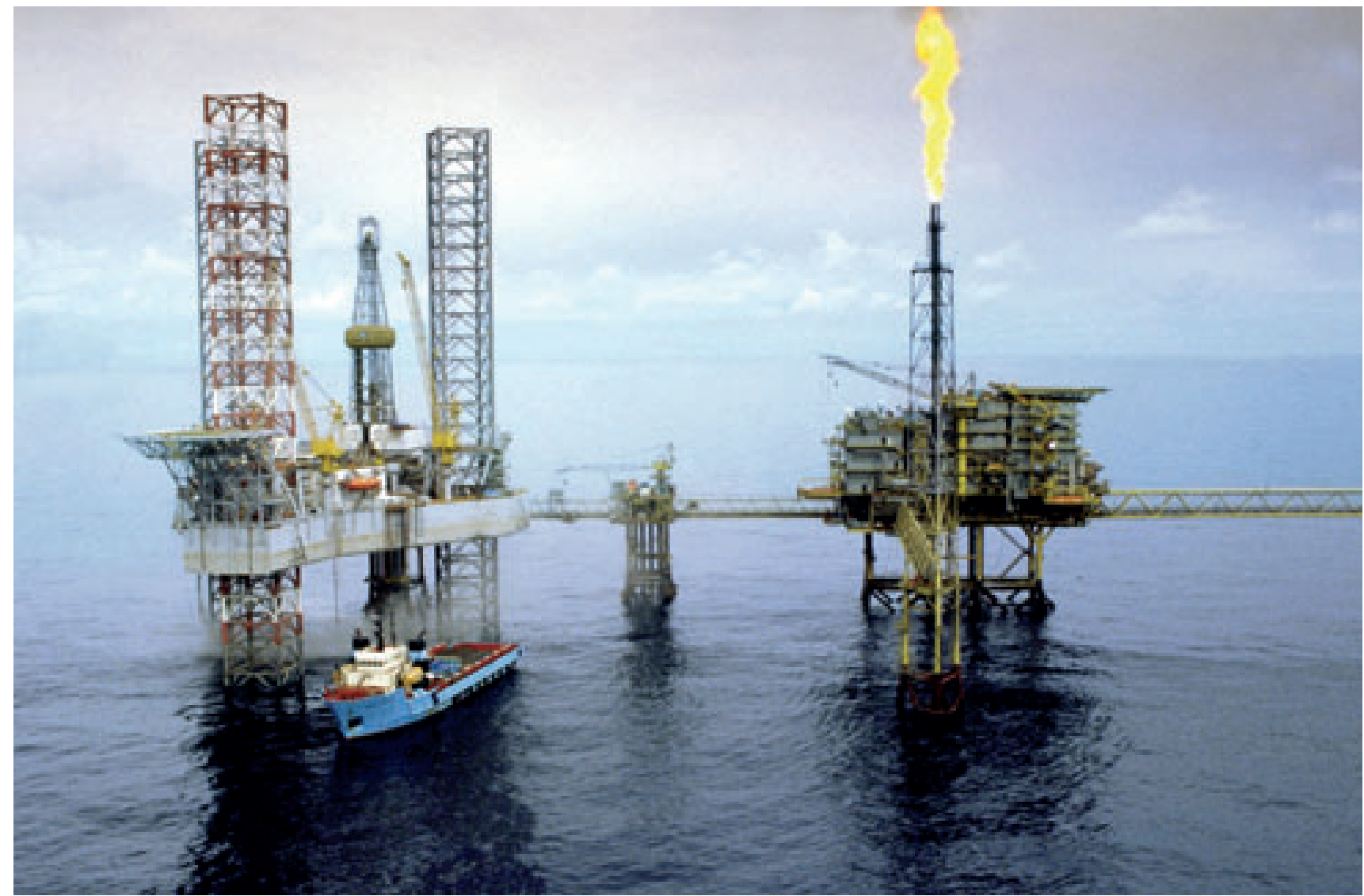

Aiemmin oli sallittua johtaa jätteitä öljynporauslautoilta, mutta OSPAR-komissio on nyt asettanut täyden kiellon jätteiden johtamiselle mereen (kuva: Steen Jacobsen/Scanpix).

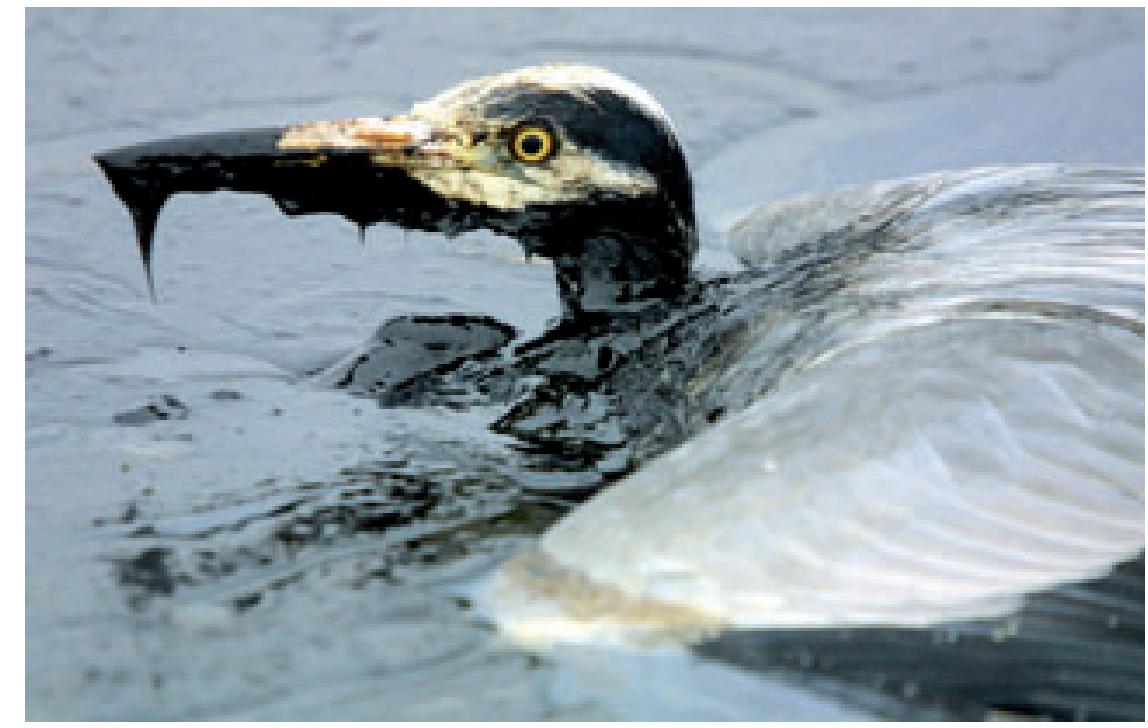

Joka vuosi monet vesilinnut kuolevat öljypäästöjen vuoksi. Tässä harmaahaikara (Ardea cinerea) on joutunut öljyn tahrimaksi (kuva: Søren Steffen/Scanpix). 


\section{Maailmanperintösopimus \\ UNESCO:n yleissopimus maailman kulttuuri- ja luonnonperinnön suojelemisesta}

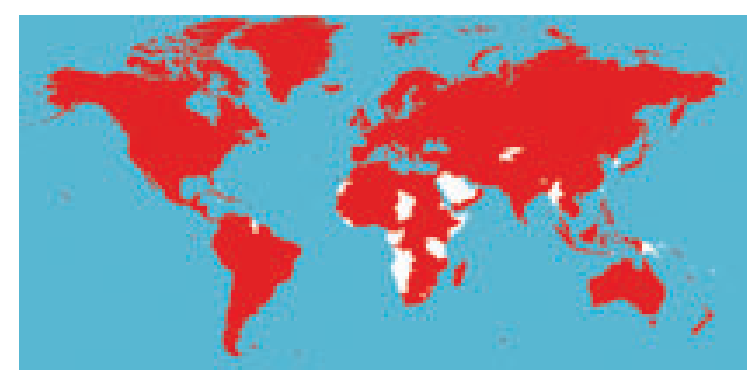

UNESCO:n jäsenmaat solmivat vuonna 1972 yleissopimuksen maailman kulttuuri- ja luonnonperinnön suojelemisesta. Yleissopimuksen taustalla oli pelko, että luonnontilaiset alueet, arkeologiset muinaisjäännökset ja kulttuuriarvot tuhoutuvat saasteiden, matkailun, sotien tai tavanomaisten rappeuttavien tekijöiden johdosta.

182 maata, mukaan lukien kaikki Pohjoismaat, ovat solmineet sopimuksen.

\section{Tarkoitus}

Maailmanperintösopimuksen tarkoituksena on säilyttää ihmiskunnan yhteistä kulttuuri- ja luonnonperintöä tuleville sukupolville.

Tavoitteena on, että yleissopimuksella kiinnitetään enemmän huomioita yhteiseen kulttuuri- ja luonnonperintöön ja että jäsenmaat takaavat luonnon- ja kulttuuriarvojen turvaamisen kansallisella lainsäädännöllä. Tavoitteena on myös luoda tehokas kansainvälinen yhteistyö kohteiden suojelemiseksi ja vaalimiseksi.

\section{Määritelmä}

UNESCO:n määritelmä luonto- ja kulttuuriperinnöstä on laaja. Se voi tarkoittaa historiallisia rakennelmia ja rakennettuja alueita, esteettistä luonnonilmiötä geologisessa tai tieteellisessä merkityksessä tai uhanalaisten kasvi- ja eläinlajien elinympäristöjä.

UNESCO:n määritelmän mukaan arvot voivat olla luonnon, ihmisen tai luonnon ja ihmisen yhteisvaikutuksen luomia.

\section{Maailmanperintöluettelo}

Kohteet, jotka muodostavat maailman kulttuuri- ja luonnonperinnön, on merkitty UNESCO:n maailmanperintöluetteloon. Jokainen yleissopimuksen solminut maa on itse vastuussa uusien kohteiden ehdottamisesta luetteloon.

21 jäsenmaan edustajista valittu Maailmanperintökomitea hyväksyy luetteloon ehdotetut kohteet. Komitea tekee päätöksen kansainvälisten asiantuntijajärjestöjen arvioinnin perusteella. Arvioinnin suorittavat - luontoarvojen kyseessä ollessa IUCN (Luonnon ja luonnonvarojen suojelua koskeva kansainvälinen liitto) ja ICOMOS (Rakennusmuistomerkkien ja historiallisten alueiden kansainvälinen neuvosto), kun kyseessä on kulttuuriarvot. Arvioinnin tarkoituksena on varmistaa, että kohteet täyttävät komitean asettamat vaatimukset kohteiden yleismaailmallisesta merkityksestä ja että kohteiden suojelu ja hoito on turvattu.

Kohteen merkitseminen maailmanperintöluetteloon edellyttää, että kyseinen jäsenmaa sitoutuu säilyttämään kohteen arvot tuleville sukupolville. Kohteille tulee laatia hoito- ja käyttösuunnitelmat. Jaksottaisella raportoinnilla seurataan kansainvälisesti kohteiden hoitoa. Mikäli kohdetta uhkaa tuho, joko voi olla luonnon tai ihmistoiminnan aiheuttama, voidaan kohde merkitä vaarantuneiden kohteiden luetteloon.

Kohteen ottaminen mukaan maailmanperintöluetteloon merkitsee erityistä arvovaltaista tunnustusta kohteelle. Lisäksi se edistää matkailua. Lisääntynyt matkailu voi merkitä kasvavia tuloja, mutta se voi myös 


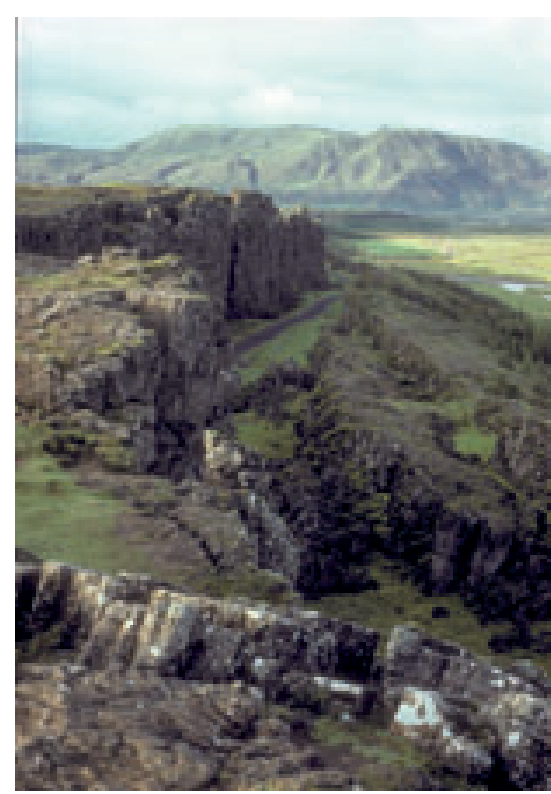

Phingvellir Islannissa on merkitty maailmanperintöluetteloon osaksi kulttuurihistoriallisin ja osaksi maisemallisin perustein. Kansankäräjät kokoontuivat phingvelliriin vuodesta 930 vuoteen 1798 (kuva: Morten Lund Overgaard).

samanaikaisesti vaikuttaa kielteisesti kohteen säilymiseen, esimerkiksi yleisen kulumisen vuoksi.

\section{Pohjoismainen yhteistyö}

Pohjoismainen maailmanperintösäätiö (Nordic World Heritage Foundation) on perustettu yhteistyön lujittamiseksi maailman luonnon- ja kulttuuriperinnön säilyttämiseksi. Säätiön tarkoituksena on mm. tukea maailmanperintösopimuksen täytäntöönpanoa jäsenmaissa, jotka ovat aliedustettuja maailmanperintöluettelossa.

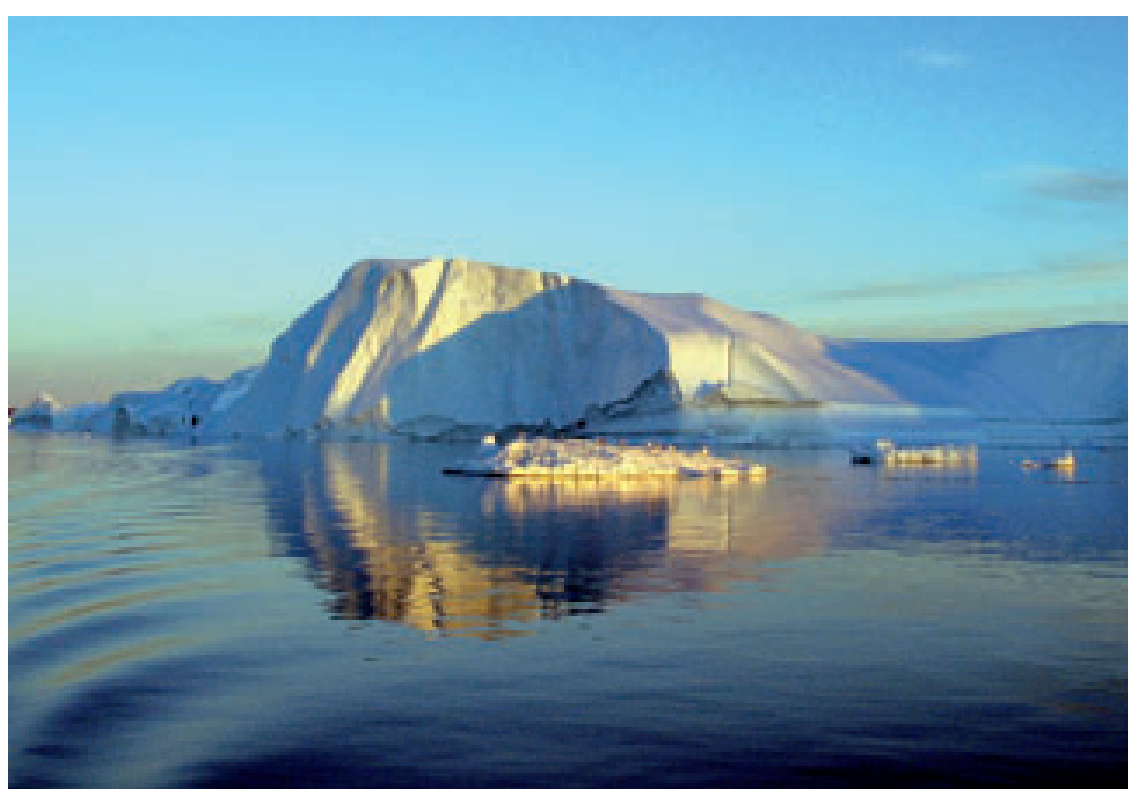

Ilulissat Isfjord on toistaiseksi Grönlannin ainoa kohde, joka on merkitty maailmanperintöluetteloon. Joka vuosi jäätiköstä irtoaa vuonoon yli 35 km³ jäätä. Jäätikkö "vasikoi”. Tutkimalla jäätiköitä tutkijat ovat saaneet tärkeätä tietoa viime jääkauden jälkeen vallitsevista ilmasto-olosuhteista (kuva: Slim Allagui/Scanpix).

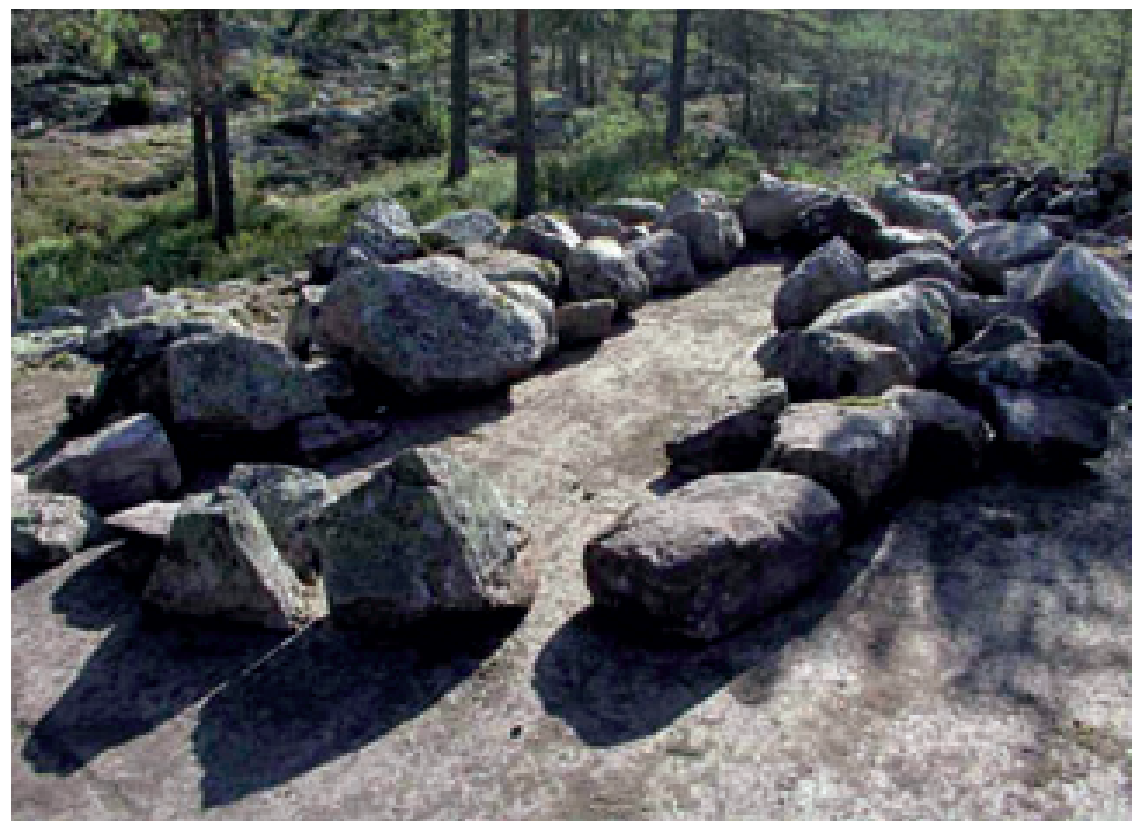

Suomessa sijaitseva Sammallahdenmäen pronssikautinen muinaisjäännösalue on merkitty maailmanperintöluetteloon. Muinaisjäännösalue antaa ainutlaatuisen kuvan Pohjois-Euroopan sosiaalisista ja uskonnollisista rakenteista yli 3000 vuotta sitten (kuva: Teija Tiitinen). whc.unesco.org www.nwhf.no 


\section{Eurooppalainen maisemayleissopimus}

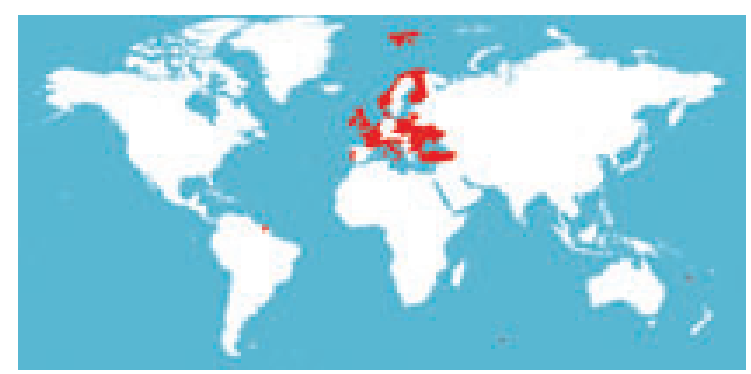

Eurooppalaisen maisemayleissopimuksen lähtökohtana on näkemys maiseman merkityksestä ihmisille. Maisema vaikuttaa ihmisen elämänlaatuun ja identiteettiin sekä kuvastaa yhteisen kulttuuri- ja luonnonperintömme monimuotoisuutta. Maisema on luonnon omien prosessien ja/tai luonnon ja ihmisen yhteistoiminnan tulos. Kaikki maisemat ovat tärkeitä ihmisten hyvinvoinnin ja viihtyvyyden kannalta.

Maisema myös muuttuu koko ajan yhteiskunnan kehittyessä esimerkiksi maanviljelyn, teollisuuden, kaupunkisuunnittelun ja matkailun piirissä.

\section{Tarkoitus}

Sopimuksen on määrä varmistaa, että meillä Euroopassa on korkealaatuisia maisemia. Sopimus edistää maiseman suojelua ja hyvää hoitoa, ja edellyttää huonokuntoisten alueiden kunnostamista. Lisäksi sopimus luo perustan eurooppalaiselle maisemayhteistyölle.

\section{Mikä maisema on?}

Sopimuksen maisemaa koskeva määritelmä on laaja ja se käsittää niin kaupunki- ja maanviljelysalu- eet kuin meri- ja luonnonalueetkin - toisin sanoen kaikentyyppiset maisemat niiden tilasta ja laadusta riippumatta.

\section{Maiseman parempi ymmärtäminen}

Edistääkseen maisemansuojelun tärkeyden ymmärtämistä jäsenmaiden velvollisuutena on lisätä kansalaisten tietoisuutta maiseman merkityksestä hyvinvointimme ja identiteettimme kannalta.

\section{Maisemapolitiikka}

Jäsenmaat ovat vastuussa maisemansuojelusta, -hoidosta ja -suunnittelusta. Jäsenmaiden tulee arvioida maisemiaan sekä asettaa niille laatutavoitteita. Kansalaisilla on mahdollisuus osallistua laatutavoitteiden asettamiseen ja vaikuttaa päätöksiin, joilla on välitöntä tai välillistä vaikutusta maiseman kehitykseen.

\section{Kansainvälinen yhteistyö} Jäsenmaat ovat velvolliset toimimaan yhteistyössä yli rajojen sekä tarvittaessa laatimaan ja toteuttamaan maisemaohjelmia yhteisesti.

\section{Hallinto}

Maisemayleissopimusta hallinnoin Euroopan neuvoston kulttuuriperintökomitea (CDPAT) ja biodiversiteettikomitea (CO-DBP).

24 maata on ratifioinut sopimuksen (8/2006), muun muassa Tanska, Norja ja Suomi. 


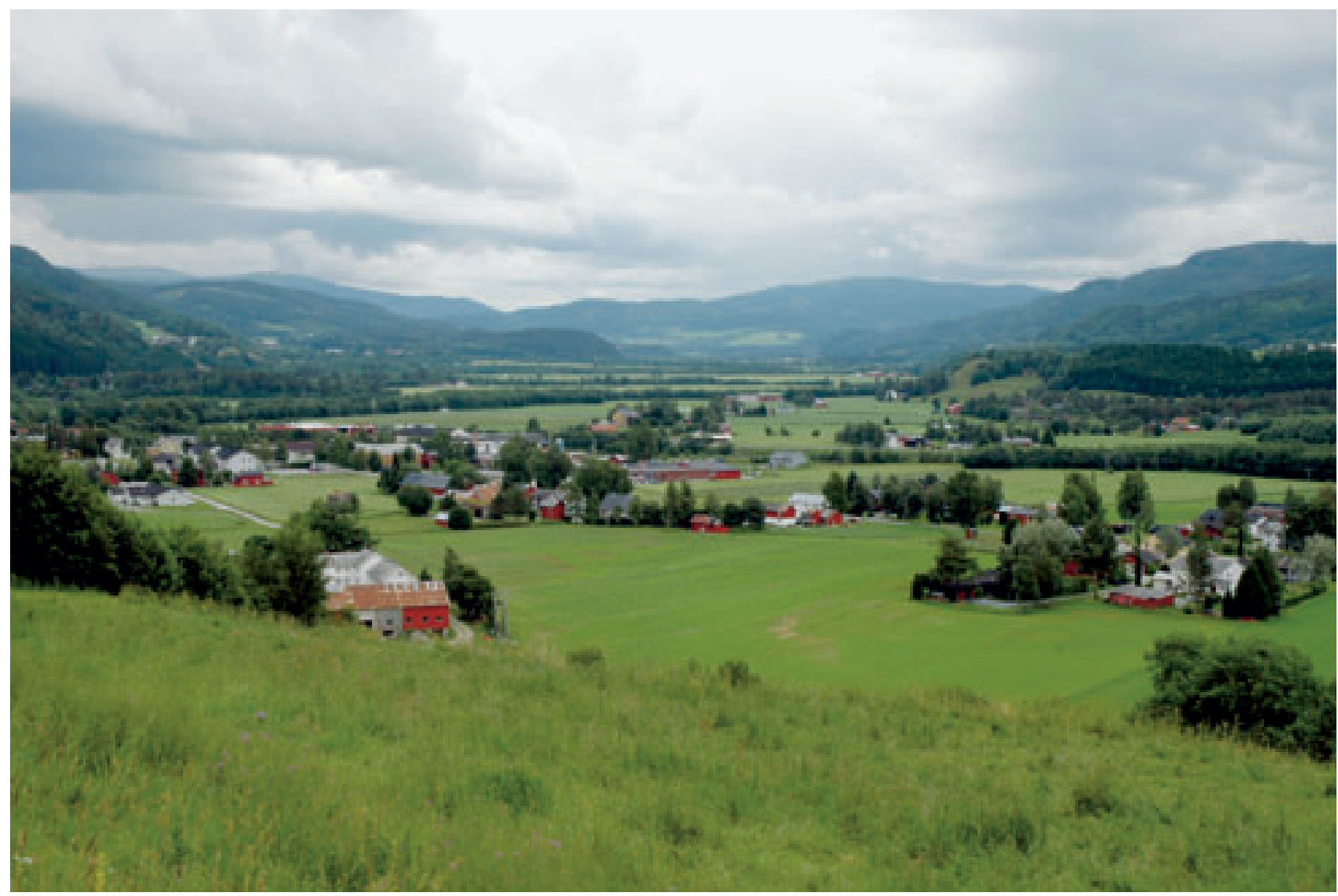

Sopimuksessa maisema määritellään alueeksi, jonka piirteet ovat luonnon ja/tai ihmisen muokkaamia (Orkdal, Norja) (kuva: Carsten Brandt).

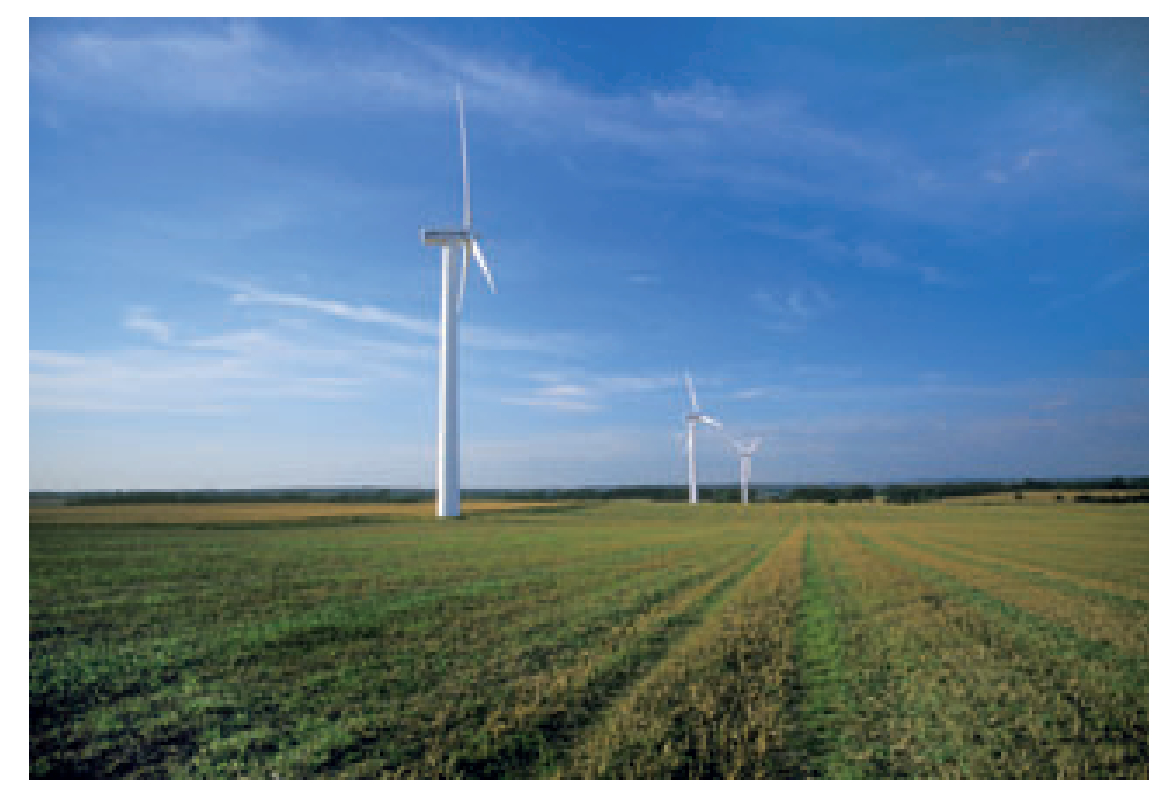

Eurooppalainen maisemayleissopimus edistää erilaisten maisema-arvojen vaalimista. Sopimus koskee kaikenlaisia maisemia, joten sekä viljellyt maisemat että maisemat, joita ihmiset eivät ole muokanneet, kuuluvat sopimuksen piiriin (kuva: Stig Bachmann Nielsen/Naturplan).

www.conventions.coe.int CETS No: 176 


\section{Granadan yleissopimus}

Euroopan rakennustaiteellisen perinnön suojelua koskeva yleissopimus

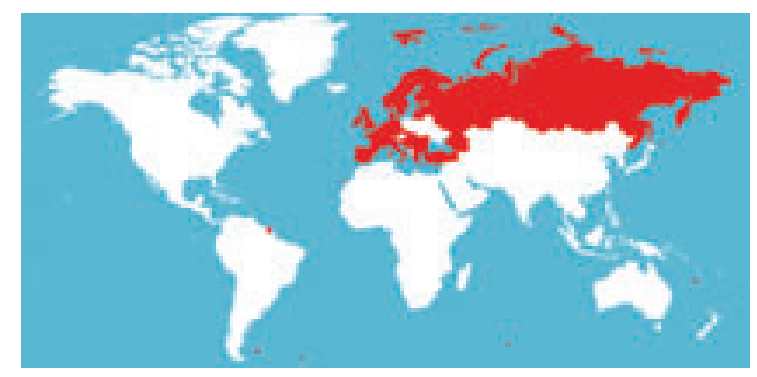

Euroopan rakennustaiteellinen perintö on rikas ja vaihteleva. Rakennustaiteeseen kätkeytyy kuva Euroopan menneisyydestä ja nykyisyydestä, joka on osa yhteistä historiaa ja identiteettiä ja elämysten ja elämänlaadun tärkeä perusta.

\section{Tarkoitus}

Granadan yleissopimuksen tarkoituksena on vahvistaa Euroopan kulttuuriperinnön säilyttämistä ja edistää tässä tehtävässä Euroopan maiden välistä yhteistyötä.

\section{Mitä rakennustaiteellinen perintö on?}

Rakennustaiteellista perintöä ovat rakennukset ja monumentit, joilla on historiallista, arkeologista tai taiteellista arvoa. Sitä ovat myös ihmisen ja luonnon vuorovaikutuksessa kehittyneet, osittain rakennetut kohteet tai alueet.

\section{Jäsenmaille asetetut vaatimukset}

Granadan yleissopimus velvoittaa jäsenmaat aktiiviseen, tavoitteelliseen rakennusperinnön suojeluun. Tavoitteiden tulee sisältyä kaupunkien ja maaseutujen maankäytön suunnitteluun ja ohjata arvokkaiden kohteiden suojelua ja restaurointia. Maiden on turvattava rakennusperintöä koskevan tiedon saatavuus siten, että se osaltaan lisää kiinnostusta niiden vaalimiseen. Lisäksi jäsenmaiden tulee kehittää yhteistyötä ja kokemusten vaihtoa rakennusperinnön suojelussa.

\section{Suojelu}

Suojelu on tärkeä väline yleissopimuksen tavoitteita toteutettaessa. Suojelu voi tapahtua joko vapaaehtoisesti tai, omistajan vastustaessa sitä, pakkolunastuksen kautta. Jäsenmaiden viranomaisilla tulee myös olla mahdollisuus määrätä omistaja pitämään suojeltua omaisuutta kunnossa ja myöntää määrärahoja suojelutehtävien toteuttamiseen.

\section{Ammatti-ihmisten koulutus} Jäsenmaiden tulee huolehtia rakennusperinnön suojelussa tarvittavasta osaamisesta kouluttamalla arkkitehteja, kaupunkisuunnittelijoita, käsityöläisiä ja muita ammattilaisia vastaamaan arvokkaiden kohteiden ja ympäristöjen suunnittelusta, suojelusta ja restauroinnista.

\section{Yleissopimuksen hallinto} Euroopan neuvoston Kulttuuriperinnön johtokomitean (CDPAT) vastuulla on sopimuksen seuranta. Komitean tulee myös edistää yleissopimuksen toimeenpanoa ja tarpeen mukaan kehittää yleissopimuksen sisältöä.

\section{Ketkä ovat mukana?}

Kaikki Pohjoismaat ovat Islantia lukuun ottamatta liittyneet sopimukseen. Tanskan liittyminen ei koske Färsaaria eikä Grönlantia. 


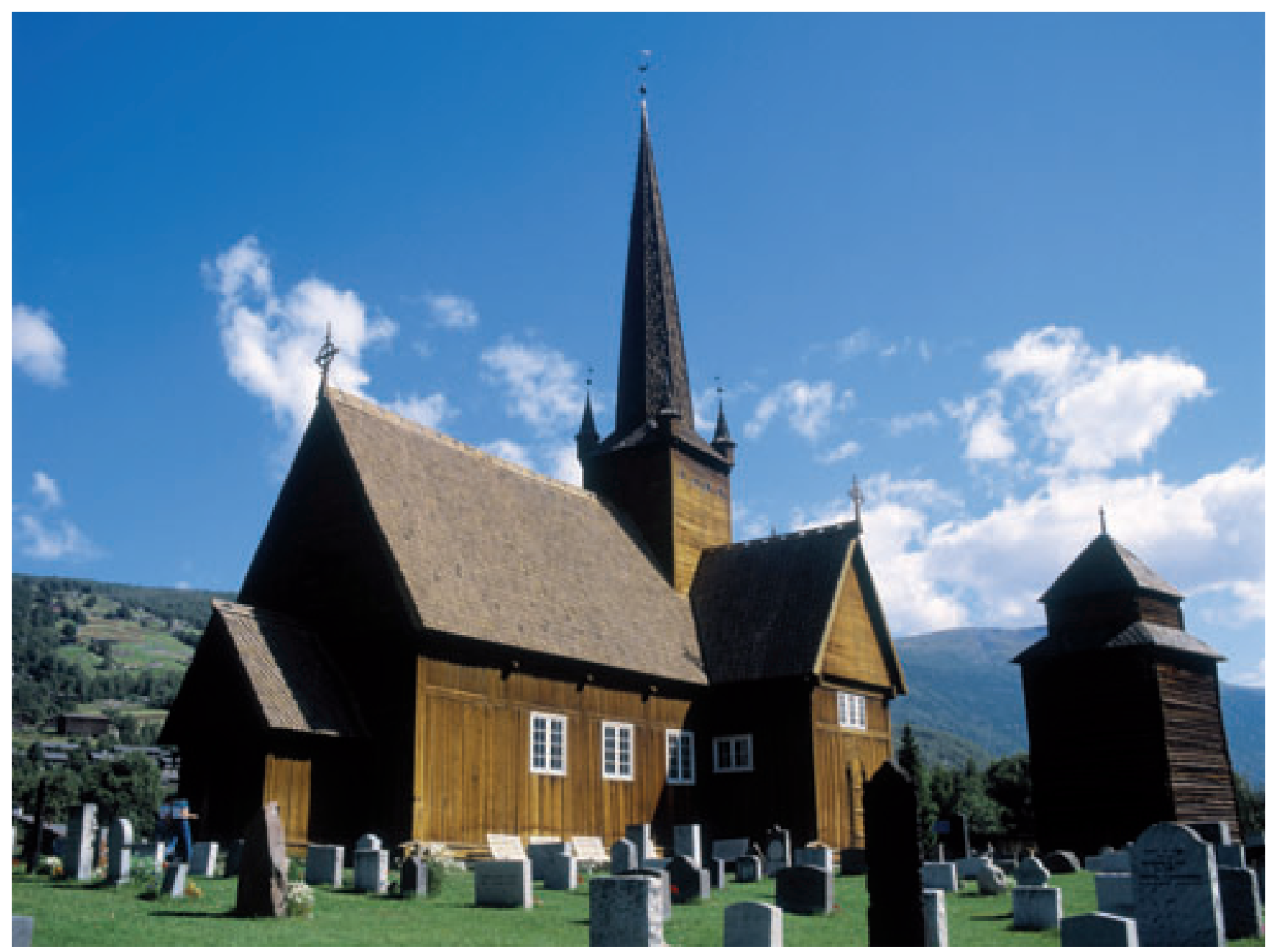

Granadan sopimus suojelee eurooppalaista arkkitehtuuriperintöä - sekä nuorempaa että vanhempaa. Norjalaiset sauvakirkot, esim. Vågåmon sauvakirkko, on esimerkki vanhemmasta arkkitehtuurista (kuva: Jan Djenner/Scanpix).

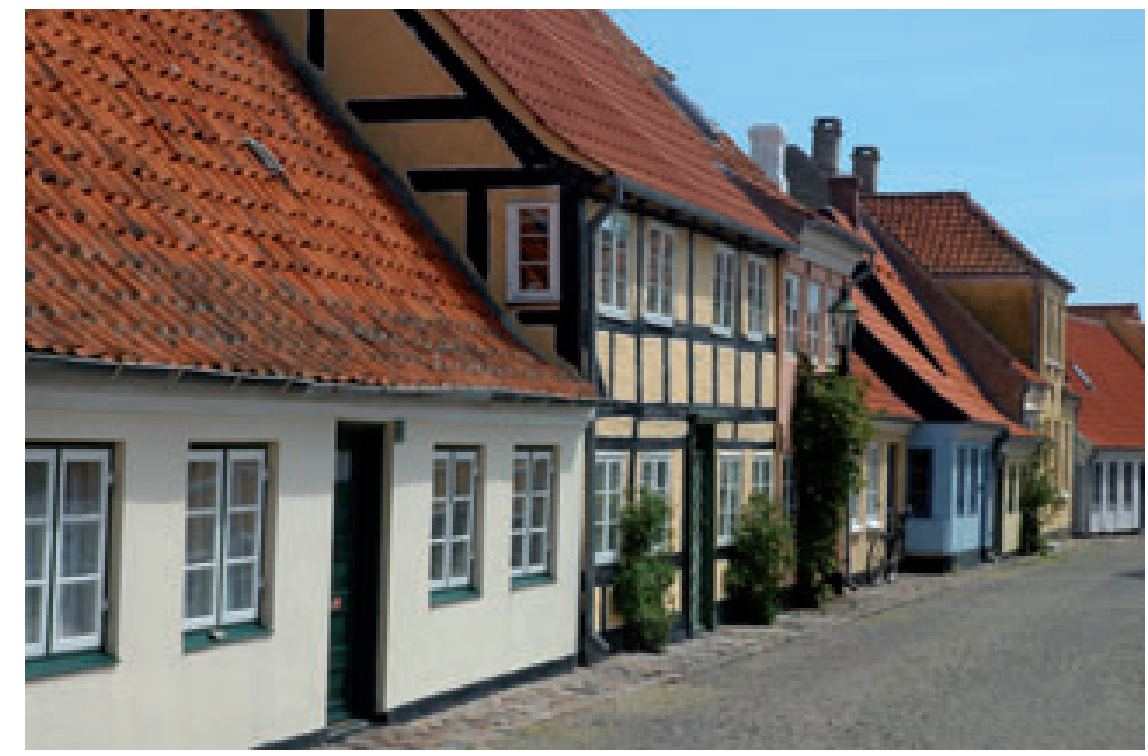

Arøskøbing on vanha tanskalainen kauppakaupunki, jossa on noin 40 vanhaa, 1700-luvulta peräisin olevaa suojeltua rakennusta (kuva: Stig Bachmann Nielsen/Naturplan).

www.conventions.coe.int CETS No.: 121 


\section{Maltan yleissopimus \\ Eurooppalainen yleissopmus arkeologisen perinnön suojelusta}

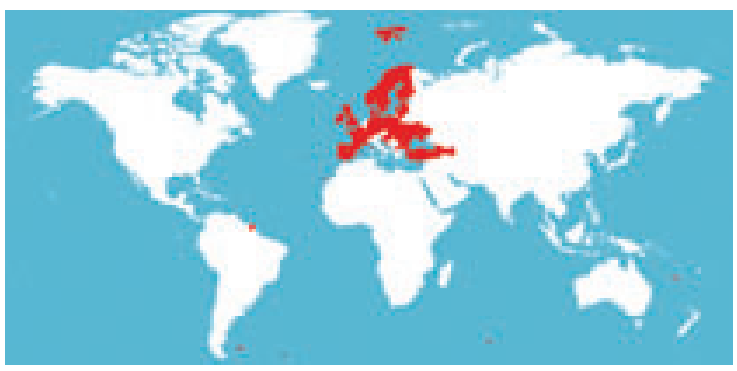

Maltan yleissopimus solmittiin Maltan pääkaupungissa Vallettassa vuonna 1992. Yleissopimus solmittiin, koska katsottiin tarpeelliseksi turvata tarkoituksenmukaisemmin arkeologinen kulttuuriperintö.

Tähän kulttuuriperintöön lasketaan kuuluvaksi rakennelmat, rakennukset, maisemat ja kohteet, jotka ovat jäännöksiä varhaisemmista aikakausista ja jotka edustavat ihmisen historiaa ja identiteettiä.

\section{Tarkoitus}

Yleissopimuksen tarkoituksena on suojella arkeologista kulttuuriperintöä Euroopan maiden yhteisen muistin lähteenä sekä historiallisen ja tieteellisen tutkimuksen aineistona. Kaikkien sellaisten varhaisempien aikakausien jäännöksien katsotaan kuuluvan arkeologiseen kulttuuriperintöön, jos

1. niiden säilyttäminen ja tutkiminen auttaa seuraamaan ihmisen historiaa ja sen suhdetta kulttuuriympäristöön,

2. löydöt, kaivaukset tai muut tutkimusmenetelmät muodostavat pääasiallisen tietolähteen ihmisen historiasta tai ympäristöstä; ja
3. ne sijaitsevat jäsenmaiden rajojen sisäpuolella.

Täyttääkseen yleissopimuksen tarkoituksen jäsenmaiden on rekisteröitävä arkelogiset löytöpaikat ja muinaisjäännökset, turvattava mahdollisuudet suojella tai hankkia arkeologisesti erityisen arvokkaita alueita ja velvoittauduttava ilmoittamaan arkeologiset löydöt julkisille viranomaisille. Maiden on otettava arkeologiset arvot huomioon fyysisen kaavoituksen ja maankäyttöhankkeiden yhteydessä. Maat ovat myös velvollisia pysäyttämään laittomat kaivaukset ja tekemään yhteistyötä yli rajojen mm. estääkseen arkeologisten esineiden laittoman viennin.

Viranomaisilla on myös oltava mahdollisuus tarjota taloudellista tukea arkeologisten arvojen säilyttämiseksi.

\section{Kokemus ja lisääntynyt huomio}

Yleissopimuksen mukaan jäsenmaiden asukkailla on oltava mahdollisuus tutustua laajasti arkeologisen perintönsä osa-alueisiin. Yleissopimus velvoittaa lisäksi maita tiedottamaan kansalaisilleen arkeologisten arvojen merkityksestä yhteiskunnan perustana. Tiedottamista voidaan myös hyödyntää väestön huomion lisäämiseksi sellaisia toimintoja kohtaan, jotka voivat tuhota muinaismuistoja ja muita arkeologisia jäännöksiä.

\section{Yleissopimuksen noudattaminen}

Euroopan neuvosto on perustanut asiantuntijakomitean - Kulttuuriperinnön johtokomitean (CDPAT) - joka on vastuussa yleissopimuksen noudattamisesta. Komitean on myös esitettävä ehdotuksia siitä, miten yleissopimuksen määräyksiä ja yleissopimuksen sisällön muutoksia voidaan paremmin toteuttaa.

\section{Ketkä ovat mukana?}

39 maata on solminut yleissopimuksen, mm. Tanska, Suomi, Norja ja Ruotsi. Tanskan liittyminen ei koske Färsaaria ja Grönlantia. 


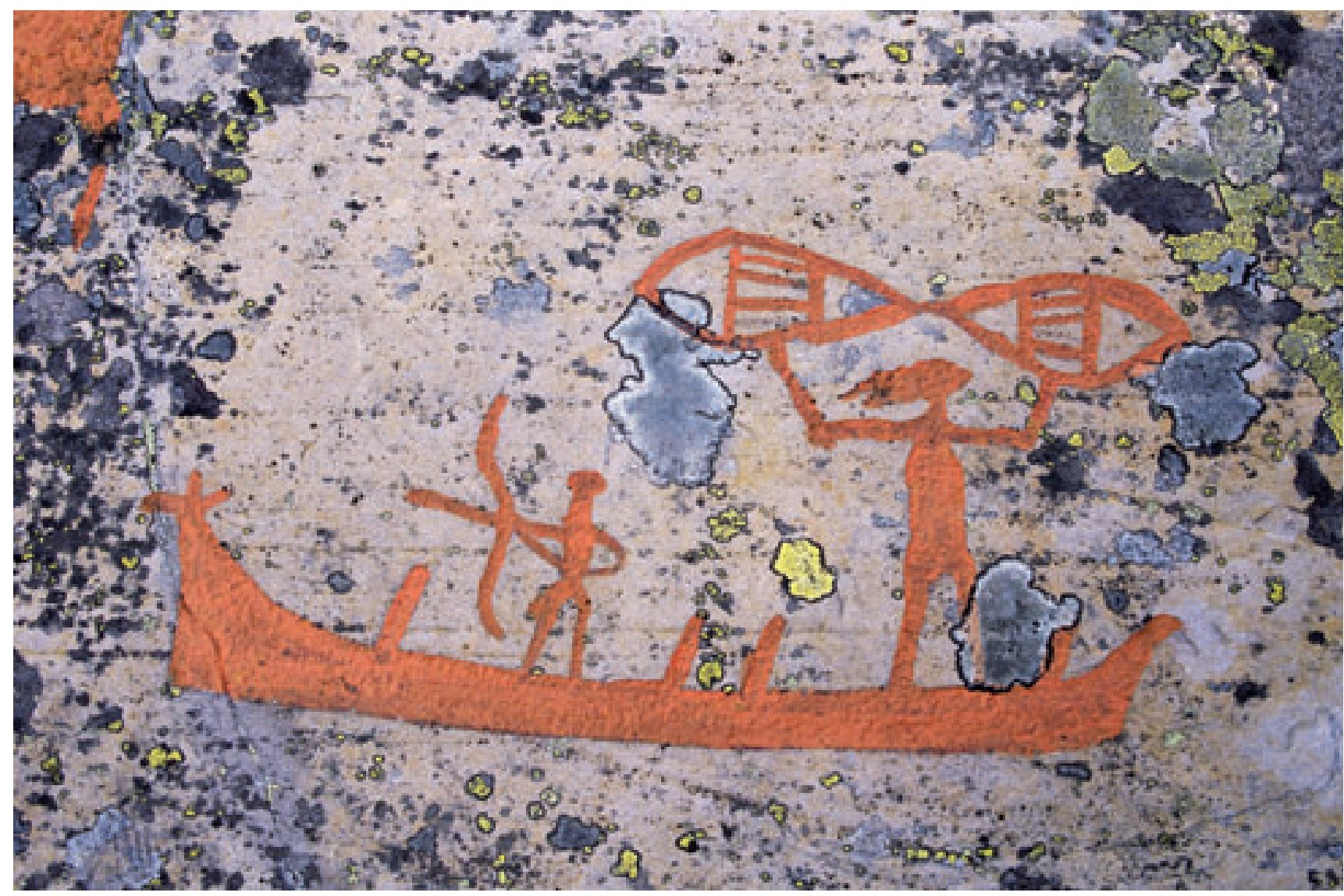

Norjalaiset kalliopiirrokset Altassa ovat osa Maltan sopimuksen kattavaa arkeologista perintöä (kuva: Sven Halling/Scanpix).

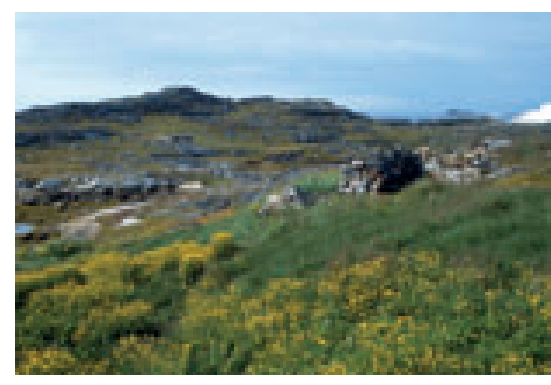

Inuiittien asuinpaikat Akian saarella esittävät Grönlannin kansan historiaa (kuva: Anders Tvevad/Scanpix).

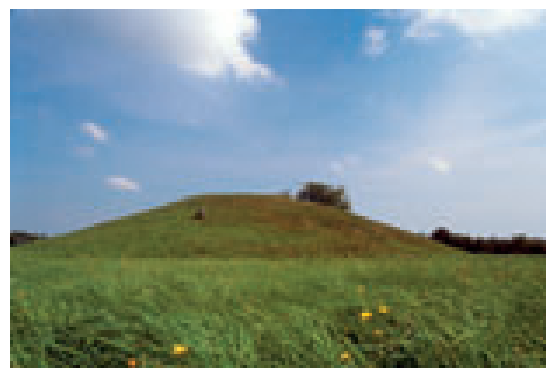

Sopimuksen mukaan väestöllä tulee olla pääsy arkeologisiin kohteisiin mukaan lukien hautakummut (kuva: Stig Bachmann/ Naturplan).

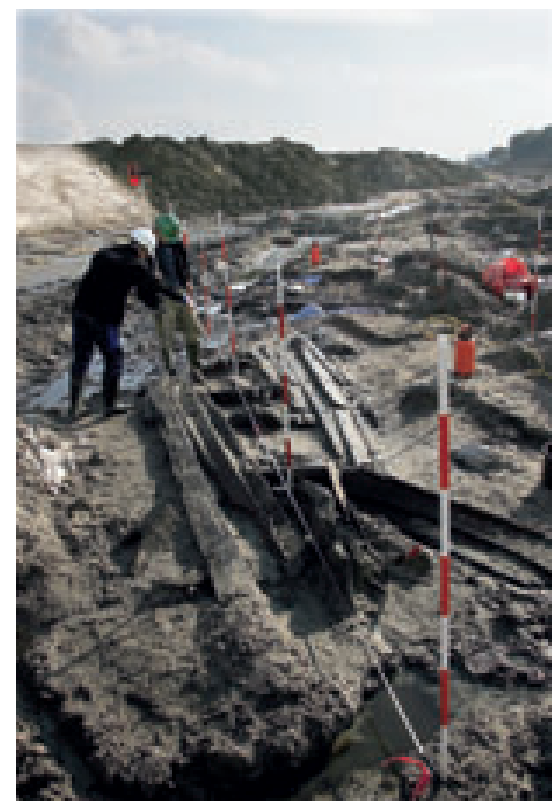

Maltan sopimus takaa, että rakennus- ja perustamistöissä otetaan huomioon arkeologiset löydöt (kuva: Jens Nørgaard Larsen/Scanpix). 


\section{Århusin yleissopimus}

\section{Yleissopimus tiedon saannista, yleisön osallistumisoikeudesta päätöksentekoon sekä muutoksenhaku- ja vireillepano-oikeudesta ympäristöasioissa}

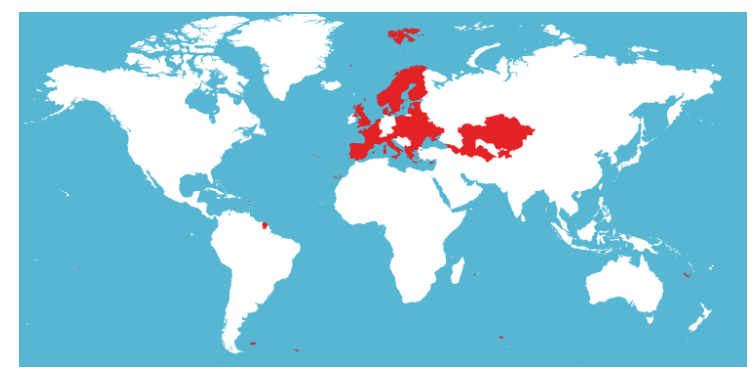

Vuonna 1998 yli 50 maan ympäristöministerit kokoontuivat Tanskan Århusissa. Siellä laadittiin Århusin yleissopimus, joka antaa kansalaisille ja järjestöille suuremmat mahdollisuudet vaikuttaa luontoa ja ympäristöä koskevaan päätöksentekoon.

\section{Tarkoitus}

Yleissopimuksen tarkoituksena on vahvistaa kolmea demokraattista perusperiaatetta:

- Tiedonsaanti

- Mahdollisuus osallistua päätöksentekoprosesseihin

- Mahdollisuus valittaa päätöksistä tuomioistuimeen tai valituslautakunnalle.

Yleissopimus koskee ainoastaan päätöksiä, joilla on merkitystä luonnon ja ympäristön kannalta.

\section{Oikeus tiedonsaantiin}

Ensimmäisen periaatteen avulla turvataan yleisön oikeus saada tietoa asioissa, jotka koskevat ympäristöä ja ihmisten elinehtoja. Oikeus tiedonsaantiin on tärkeä edellytys sille, että kansalaiset voivat olla mukana vaikuttamassa viranomaisten tekemiin päätöksiin. Yleissopimuksen mukaan tämä oikeus tulee olla kaikilla henkilöillä kansallisuudesta, kansalaisuudesta ja asuinpaikasta riippumatta.

\section{Oikeus osallistua päätöksentekoprosessiin} Ei riitä, että tieto on yleisön saatavilla. Ihmisillä tulee myös olla mahdollisuus vaikuttaa siihen, mitä päätetään. Jäsenmaat sitoutuvat siksi ottamaan yleisön mukaan päätöksentekoprosessiin ympäristöasioissa esim. julkisten kuulemisten ja yleisötilaisuuksien kautta. Yleisöllä tulee $\mathrm{mm}$. olla mahdollisuus vaikuttaa sellaisiin päätöksiin, jotka koskevat uusia, luontoa saastuttavia tai muulla tavoin ympäristöön vaikuttavia toimintoja.

\section{Oikeus muutoksenhakuun}

Sopimuksen tulee taata, että sellaisilla kansalaisilla, toiminnoilla ja järjestöillä, joita asia koskee, on oikeus muutoksenhakuun asiakirjojen tiedonsaannissa ja toiminnoissa, jotka voivat vaikuttaa ympäristöön. Yleissopimuksessa on myös laajempi määräys siitä, miten yleisön tulee voida panna asia vireille ja sillä tu- lee olla oikeus valittaa päätöksistä luontoa, ympäristöä ja kaavoitusta koskevan lainsäädännön sisällä.

Jokainen maa päättää itse, kenellä kussakin konkreettisessa tapauksessa on riittävä peruste valittaa asiassa.

Tähän asti 40 maata on allekirjoittanut yleissopimuksen, näiden joukossa kaikki Pohjoismaat Islanti, Färsaaria ja Grönlantia lukuun ottamatta. 


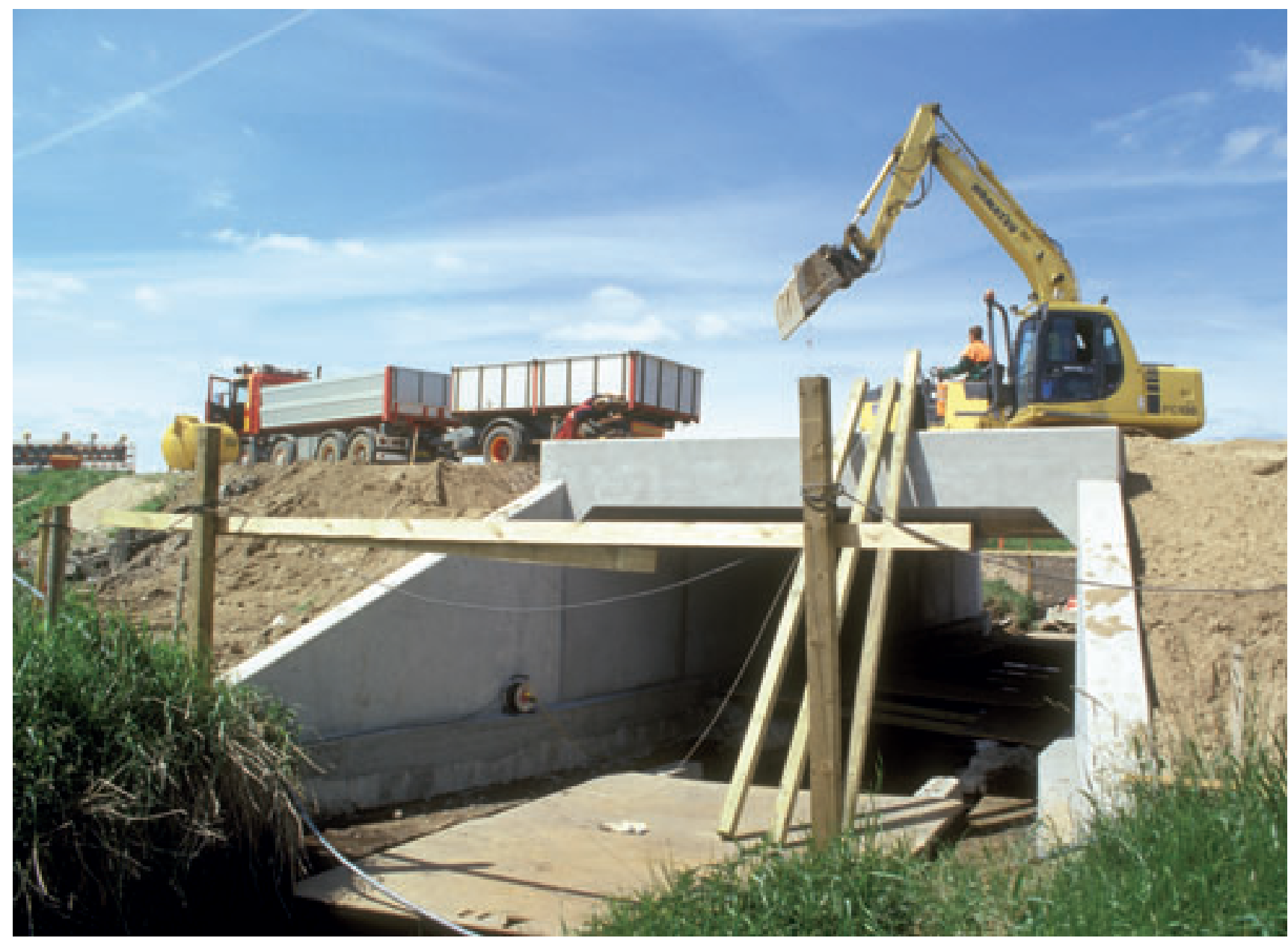

Århusin sopimus on solmittu varmistamaan, että kansalaisilla on oikeus saada tietoa, osallistua päätöksentekoprosessiin ja valittaa päätöksistä, jotka koskevat sellaisia toimia, joilla voi olla epäedullisia vaikutuksia ympäristöön (kuva: Jens Muff Hansen/Naturplan).

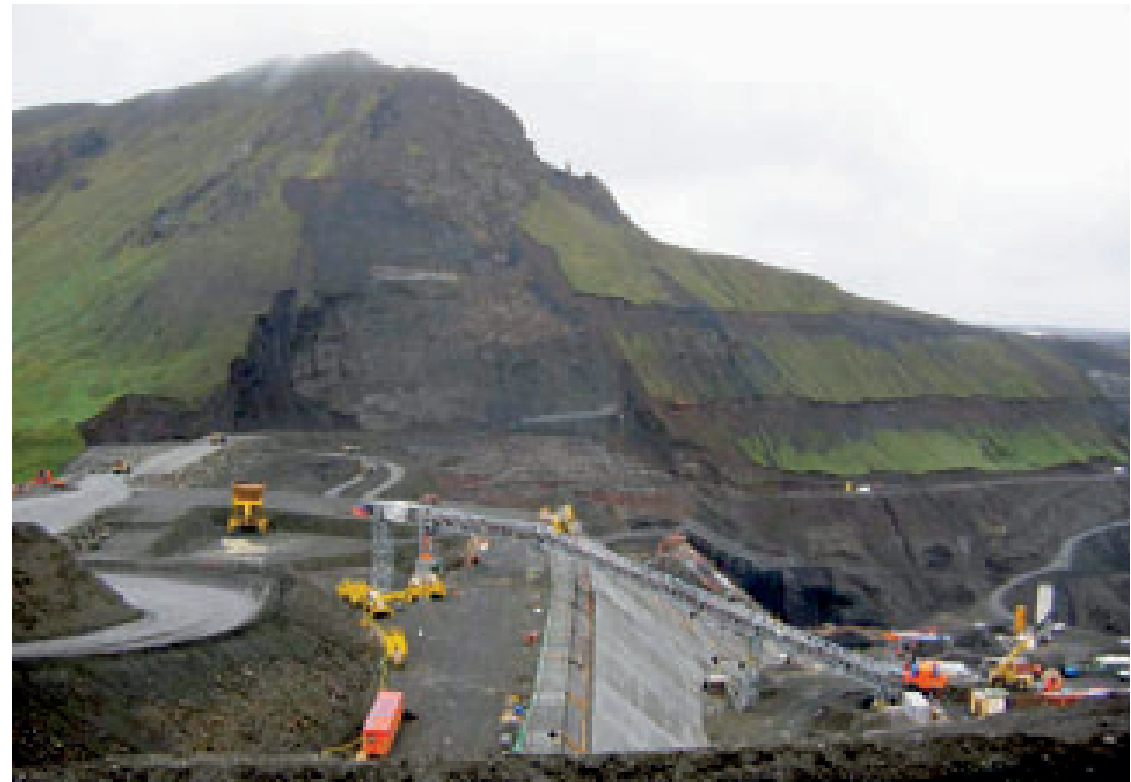

Valitusoikeus koskee mm. perustamistöitä kuten esim. tuulivoimala Kárahnjúkarin rakentamista Islantiin (kuva: Magnea I. Kristinsdóttir).

www.unece.org/env/pp 


\section{Kansainväliset sihteeristöt}

Biodiversiteettisopimus:

(The Convention on Biological Diversity)

Secretariat of the Convention on Biological Diversity

413 St-Jacques Street, 8th floor, Office 800

Montreal, Quebec, Canada, $\mathrm{H}_{2} \mathrm{Y}_{1} \mathrm{~N} 9$

Puhelin: +1-514-288-2220

Telekopio: +1-514-288-6588

Sähköposti: secretariat@biodiv.org

Kotisivu: www.biodiv.org

\section{CITES-sopimus:}

(The Convention on International Trade in Endangered Species of Wild Fauna and Flora)

UNEP/Regional Office for Europe - International Environment House

15, chemin des Anémones $\mathrm{CH}-1219$ - Châtelaine, Geneva

- Switzerland

Puhelin: +41-22-917 8279

Telekopio: +41-22-917 80 24

Sähköposti: roe@unep.ch

Kotisivu: www.cites.org

\section{Ramsarin yleissopimus:}

(The Convention on Wetlands of International Importance especially as Waterfowl Habitat)

Ramsar Convention Secretariat,

Rue Mauverney 28,

$\mathrm{CH}-1196$ Gland, Switzerland

Puhelin: +4122999 0170, +41229990169,

Sähköposti: ramsar@ramsar.org

Kotisivu: www.ramsar.org

\section{Bernin yleissopimus:}

(The Convention on the Conservation of European Wildlife and Natural Habitats)

Council of Europe

Avenue de l'Europe

67075 Strasbourg Cedex

Puhelin: +33(0)388412000

Kotisivu: http://www.conventions.coe.int

Bonnin yleissopimus:

(The Convention on Migratory Species of Wild Animals)

UNEP / CMS Secretariat

United Nations Premises

Martin-Luther-King-Str. 8

D-53175 Bonn, Germany

Puhelin: (+49 228) $8152401 / 02$

Telekopio: (+49 228) 8152449

Sähköposti: secretariat@cms.int

Kotisivu: www.cms.int

\section{Valaanpyynnin säätelyä koskeva kansainvälinen}

yleissopimus:

(The International Convention for the Regulation of Whaling)

The International Whaling Commission

The Red House,

135 Station Road,

Impington,

Cambridge,

Cambridgeshire CB4 9NP, UK.

Puhelin: +44 (o) 1223233971

Telekopio: +44 (o) 1223232876

Sähköposti: secretariat@iwcoffice.org

Kotisivu: www.iwcoffice.org
Helsingin yleissopimus:

(The Convention on the Protection of the Marine Environment of the Baltic Sea Area)

Helsinki Commission

(The Baltic Marine Environment Protection Commission)

Katajanokanlaituri 6 B

Fl-00160 Helsinki, Finland

Puhelin: +35896220220

Telekopio: +358962202239

Kotisivu: www.helcom.fi

\section{OSPAR-sopimus:}

(The Convention for the Protection of the Marine Environment of the North-East Atlantic)

OSPAR Secretariat

New Court

48 Carey Street

London WC2A 2JQ / UK

TPuhelin: +44 (0) 2074305200

Telekopio: +44 (o) 2074305225

Sähköposti: secretariat@ospar.org

Kotisivu: www.ospar.org

\section{Maailmanperintösopimus:}

(The Convention Concerning the Protection of the World Cultural and Natural Heritage)

The World Heritage Centre UNESCO

7, place de Fontenoy

75352 Paris 07 SP, France

Puhelin: $33-1-45681571$

Telekopio: 33-1-45 685570

Sähköposti:wh-info@unesco.org

Kotisivu: www.unesco.org

Nordic World Heritage Foundation

Fridtjof Nansens Plass 4

0160 Oslo, Norway

Sähköposti: nwhf@nwhf.no

Kotisivu: www.nwhf.no

Eurooppalainen maisemayleissopimus

(The European Landscape Convention)

Granadan yleissopimus

(The Convention for the Protection of the Architectural Heritage of Europe)

Maltan yleissopimus

(The European Convention on the Protection of the Archaeolo-

gical Heritage)

Council of Europe

Avenue de l'Europe

67075 Strasbourg Cedex

Puhelin: +33(0)388412000

Kotisivu: www.conventions.coe.int

\section{Århusin yleissopimus}

(The Convention on Access to Information, Public Participation in Decision-making and Access to Justice in Environmental Matters)

Aarhus Convention Secretariat

United Nations Economic Commission for Europe

Environment and Land Management Division

Palais des Nations

1211 Geneva 10, Switzerland

Puhelin: + 41229174226 / 9171502

Telekopio: + 41229070107

Sähköposti: public.participation@unece.org

Kotisivu: www.unece.org/env/pp 


\title{
Tanska
}

Biodiversiteeettisopimus

www.skovognatur.dk

CITES-sopimus

Ramsarin yleissopimus

Bernin yleissopimus

Bonnin yleissopimus

Valaanpyynnin säätelyä koskeva kansainvälinen yleissopimus

Helsingin yleissopimus

OSPAR-sopimus

Maailmanperintösopimus

Eurooppalainen maisemayleissopimus

Granadan yleissopimus

Maltan yleissopimus

Århusin yleissopimus

www.skovognatur.dk

www.skovognatur.dk

www.skovognatur.dk

www.skovognatur.dk

www.skovognatur.dk

www.mst.dk

www.mst.dk

www.unesco.dk

ww.skovognatur.dk

www.kuas.dk

www.kuas.dk

www.mst.dk

\section{Färsaaret}

Biodiversiteettisopimus

Ramsarin yleissopimus

Bonnin yleissopimus

Valaanpyynnin säätelyä koskeva kansainvälinen yleissopimus

OSPAR-sopimus

\section{Suomi}

Biodiversiteettisopimus

CITES-sopimus

Ramsarin yleissopimus

Maailmanperintösopimus

Eurooppalainen maisemayleissopimus

Århusin yleissopimus

\section{Islanti}

Biodiversiteettisopimus

CITES-sopimus

Ramsarin yleissopimus

Bernin yleissopimus

Valaanpyynnin säätelyä koskeva kansainvälinen yleissopimus OSPAR-sopimus

Maailmanperintösopimus

Århusin yleissopimus

\section{Norja}

Biodiversiteettisopimus

CITES-sopimus

Ramsarin yleissopimus

Bernin yleissopimus

Bonnin yleissopimus

Valaanpyynnin säätelyä koskeva kansainvälinen yleissopimus

OSPAR-sopimus

Maailmanperintösopimus

Eurooppalainen maisemayleissopimus

Granadan yleissopimus

Maltan yleissopimus

Århusin yleissopimus

\section{Ruotsi}

Biodiversiteettisopimus

CITES-sopimus

Ramsarin yleissopimus

Bernin yleissopimus

Bonnin yleissopimus

Helsingin yleissopimus

OSPAR-sopimus

Maailmanperintösopimus

Eurooppalainen maisemayleissopimus

Granadan yleissopimus

Maltan yleissopimus

Århusin yleissopimus

www.imr.fo

www.imr.fo

www.imr.fo

www.fisk.fo

www.imr.fo

www.ymparisto.fi

www.ymparisto.fi

www.ymparisto.fi

www.nba.fi/en/whf

www.ymparisto.fi

www.ymparisto.fi

www.umhverfisraduneyti.is

www.ust.is

www.ust.is

www.ni.is

www.sjararutvegsraduneyti.is www.umhverfisraduneyti.is www.menntamalaraduneyti.is www.umhverfisraduneyti.is

\author{
www.miljo.no \\ www.miljo.no \\ www.miljo.no \\ www.miljo.no \\ www.miljo.no \\ www.miljo.no \\ www.miljo.no \\ www.miljo.no \\ www.miljo.no \\ www.miljo.no \\ www.miljo.no \\ www.miljo.no
}

www.regeringen.se

www.sjv.se

www.naturvardsverket.se

www.naturvardsverket.se

www.naturvardsverket.se

www.naturvardsverket.se

www.naturvardsverket.se

www.unesco-sweden.org

www.raa.se

www.raa.se

www.raa.se

www.naturvardsverket.se 



\section{norden}

Pohioismaiden ministerineuvosto

Store Strandstræde 18

DK-1255 København K

www.norden.org

\section{Rikkaampi tulevaisuus}

13 yleissopimusta luonnon ja kulttuuriympäristön hyväksi

Pohjoismailla on pitkät perinteet osallistumisessa kansainväliseen yhteistyöhön maailman luonnon- ja kulttuuriperinnön säilyttämiseksi. Tässä yhteistyössä yleissopimukset muodostavat tärkeän työkalun.

Vihkosessa esitellään 13 tärkeintä yleissopimusta, jotka eri laajuuksissa koskevat Pohjoismaita ja joiden luomiseen Pohjoismaat ovat useissa tapauksissa osallistuneet. Yleissopimukset ovat:

- Biodiversiteettisopimus

- CITES-sopimus

- Ramsarin yleissopimus

- Bernin yleissopimus

- Bonnin yleissopimus

- Valaanpyyntisopimus

- Helsingin yleissopimus

- OSPAR-sopimus

- Maailmanperintösopimus

- Eurooppalainen maisemayleissopimus

- Granadan yleissopimus

- Maltan yleissopimus

- Århusin yleissopimus

Vihkosessa annetaan lyhyt kuvaus yleissopimusten historiallisesta taustasta. Myös tärkeimmät päätökset ja niiden merkitys Pohjoismaille käydään läpi.

Vihkonen sisältää myös katsauksen siihen, missä yleissopimuksessa kukin Pohjoismaa on mukana ja mistä saa lisätietoja.

Kohderyhmänä on poliitikot, virkamiehet, hallintovirkamiehet, opettajat, eturyhmät ja muut luonnon- ja kulttuuriperinnöstä kiinnostuneet. 